\title{
Os judeus da Beira interior: a comuna de Trancoso e a entrada da Inquisição
}

\author{
Maria José Ferro Tavares* \\ Lisboa**
}

Los Judíos de la Beira Interior: la aLjama de Trancoso y la entrada de la Inquisición.Este artículo analiza la presencia judía en la región portuguesa rayana de la Beira interior, desde sus orígenes hasta el presente, en que han permanecido ciertas tradiciones y memorias en torno a la comunidad de Belmonte. Especial atención se dedica a la aljama medieval de Trancoso, una de las más importantes de esta región, a través de un enfoque diacrónico, que repasa sus inicios en un contexto ibérico, la biografía de alguno de sus componentes y su importancia en el desarrollo económico regional, sin olvidar el trauma que supuso la irrupción de la Inquisición, con la prisión y fuga de conversos a otras ciudades del reino y hacia la vecina Castilla.

Palabras Clave: Beira; aljamas; Trancoso; bautismo forzado; Inquisición; diáspora.

The Jews in the Beira Interior: the Trancoso Comuna and the coming of the Inquisition.The article analyzes the Jewish presence in the Portuguese region of the Beira interior from its origins until present times, where some traditions and memories regarding the Belmonte community have been preserved. It focuses on the Jewish medieval community of Trancoso, one of the most relevant in the region, analyzing its origins in an Iberian context, the biography of some of its members and its importance in the regional economic development. Finally, the irruption of the Inquisition are and its dramatic consequences is considered.

KeYwords: Beira; Jewish Communities; Trancoso; Forced Conversion; Inquisition; Diaspora.

Se procurarmos a memória dos judeus portugueses, verificamos que ela perdurou até aos nossos dias no interior beirão e transmontano no romanceiro popular e em tradições religiosas, onde o judaísmo se cruzava com o cristianismo imposto. Abade de Baçal ${ }^{1}$, Leite de Vasconcelos ${ }^{2}$, Amílcar Paulo ${ }^{3}$,

*mariajosetavares@gmail.com

** Catedrática jubilada, Universidade Aberta.

${ }^{1}$ Francisco Manuel Alves, Memórias arqueológico-históricas do distrito de Bragança. Os Judeus no distrito de Bragança (Bragança 1971 [ed. original 1925]).

2 J. Leite de Vasconcelos, Etnografia Portuguesa, vol. IV (Lisboa 1980).

${ }^{3}$ Amílcar Paulo, Os judeus secretos em Portugal ([Porto] 1985). 
Samuel Schwarz ${ }^{4}$, e, mais recentemente, David Canelo ${ }^{5}$, Maria Antonieta Garcia ${ }^{6}$ ou Adriano Vasco Rodrigues ${ }^{7}$ fizeram-se eco de uma memória etnológica, ainda viva — embora infelizmente em vias de extinção- que procuraram completar com o conhecimento histórico, por vezes, presente numa ou noutra rara inscrição em pedra, como a que Samuel Schwarz ${ }^{8}$ relacionou com uma pouco provável sinagoga em Belmonte no século XIII, ou a mais recente inscrição de uma sinagoga em Gouveia ${ }^{9}$, em vésperas da expulsão.

Amílcar Paulo escrevia, em meados do século XX, o seguinte:

$\mathrm{Na}$ Beira, há ainda povoados que vivem em usos de sinagoga e o mesmo acontece em muitas povoações raianas de Trás-os-Montes. Chamam-se a si mesmos «gente de nação» e crêem-se, em verdade, um povo à parte, mas já não têm a noção de que povo é esse. Para os seus ritos, dum judaísmo oculto e tímido, usam reunir-se em casa uns dos outros. E, nessas reuniões, são principalmente as mulheres que recitam, por tradição oral, rezas e salmos de acentuada origem hebraica ${ }^{10}$.

Belmonte, Pinhel, Covilhã, Fundão foram lugares na Beira, onde estes autores coligiram orações e ritos de origem judaica que, em pleno século XX, ainda se mantinham vivos. No entanto, se cotejarmos os espaços desta memória recente, verificamos que nem sempre eles coincidem com a informação documental, como no caso de Belmonte, sendo forçoso que remetamos a sua sobrevivência para uma presença tardia (finais do século XV), e, provavelmente, mais cristã nova do que anterior ao baptismo forçado da minoria, pelo que próxima dos últimos tempos da presença judaica em Portugal.

Não temos qualquer dúvida em afirmar que a presença dos seguidores da Lei de Moisés por estas paragens é antiga e remonta, pelo menos, à outorga dos foros e costumes a alguns destes territórios pelos reis de Portugal, embora alguns

\footnotetext{
${ }^{4}$ Samuel Schwarz, Os cristãos novos em Portugal no século XX (Lisboa 1925).

5 David Canelo, Os últimos judeus secretos (Belmonte 1985); IDEM, Os últimos Criptojudeus em Portugal (Belmonte 1987).

${ }^{6}$ Maria Antonieta Garcia, Os Judeus de Belmonte. Os caminhos da memória (Lisboa [1993?]).

7 Adriano Vasco Rodrigues, Provérbios de origem sefardita no interior da Beira e em Trásos-Montes (Mogadouro 2004).

${ }^{8}$ Samuel Schwarz, «Inscrições hebraicas em Portugal», Arqueologia e História 1 (Lisboa 1922), pp. 124-168.

9 Manuel A. Rodrigues, «A inscrição hebraica de Gouveia», O Instituto 130 (Coimbra 1968), pp.6-27.

${ }^{10}$ Paulo, Os judeus secretos, p. 26.
} 
destes foros pertençam ao domínio leonês, como acontece em Castelo Rodrigo que, tal como os de Castelo Melhor e de Castelo Bom, estão datados de 1209. Neles se mencionavam as multas que incidiam sobre todo aquele que ferisse um judeu, as quais oscilavam entre 2 e 4 morabitinos de ouro, devendo ser os testemunhos apresentados com testemunhas cristãs e judias. Os foros de Alfaiates e de Castelo Melhor legislavam sobre o empréstimo a juro, feito por judeus ${ }^{11}$.

No entanto, estes foros, também designados de Riba Côa, pelo facto de terem uma origem leonesa e pertencerem a terras incorporadas no reino de Portugal com o tratado de Alcanices, em 1297, poderão não comprovar uma tão remota presença judaica em território português da Beira interior ${ }^{12}$. Podemos, porém, afirmar sem reservas que, pelo menos, desde D. Afonso III encontramos indivíduos da minoria a residir na Guarda. De facto, os foros deste concelho mencionavam a existência de judeus e transcreviam a legislação do Bolonhês contra a usura e o empréstimo judaicos. Das inquirições do mesmo soberano se extrai que nos foros dos termos de Gardão havia uma «Póvoa de judeus», cuja memória se perdeu, excepto a do topónimo ${ }^{13}$.

\section{AS COMUNIDADES JUDAICAS DA BEIRA INTERIOR: BREVE ABORDAGEM}

Pertencem a D. Dinis as mais antigas minutas de cartas de confirmação de privilégios a comunas de judeus do reino, entre as quais constam as das comunidades de Castelo Rodrigo, Sabugal, Monforte e Guarda. Nada encontrámos sobre a existência de judeus, durante a centúria de Trezentos, em Alfaiates e em Castelo Bom, devendo nós concluirmos, com base no numeramento de 1496 que eles nunca habitaram naqueles concelhos ${ }^{14}$, como veremos.

$\mathrm{Na}$ Guarda, os judeus residiam num espaço do município que era propriedade do rei e, por isso, possuímos informações abundantes sobre a sua comuna, a localização da rua dos judeus e os seus habitantes. A judiaria ou judaria ${ }^{15}$

11 Portvgaliae Monvmenta Histórica. Leges et Consvetvdines, vol. I (Lisboa 1856), pp. 865, 911 e 789, respectivamente; Fortunato de Almeida, História da Igreja em Portugal (2 $2^{\text {a }}$ ed., Porto 1967), vol. I, pp. 207 e 209; Maria José Ferro Tavares, Os Judeus em Portugal no século XIV (Lisboa, $2^{\mathrm{a}}$ ed., 1999 [1 $1^{\mathrm{a}}$ ed., Lisboa 1970]), p. 16.

12 O tratado de Alcanices e a importância histórica das terras de Riba Côa. Actas do Congresso Histórico Luso-Espanhol (Lisboa 1998).

13 «Foros da Guarda», in Livros Inéditos de História Portugueza (Lisboa 1926), t ${ }^{\circ} \mathrm{V}, \mathrm{pp} .433$ e 448; Almeida, História da Igreja, vol. I, p. 206, nota 6.

14 João Alves DiAs, «A Beira interior em 1496 (Sociedade, administração e demografia)», in Ensaios de História Moderna (Lisboa 1988), pp. 69-72.

15 Não querendo entrar em polémica sobre possível xenofobia linguística, utilizarei os vocábulos judiaria e judaria indistintamente, embora o primeiro seja o mais vulgarizado, hoje, e o último ou «juderia» o mais empregue na Idade Média. 
principiava próximo da porta d'el-rei e terminava junto ao adro da igreja de $\mathrm{S}$. Vicente, tal como ainda hoje persiste na memória toponímica da cidade ${ }^{16}$. De 1316, datava a mais antiga referência à chancelaria do arrabiado da Beira, que valia para a coroa 100 libras por ano. Nela eram mencionadas as 80 libras anuais que os judeus de Castelo Rodrigo pagavam ao rei de peita real, enquanto os de Monforte eram colectados em $40{ }^{17}$.

No entanto, parece-nos, haver necessidade de distinguir entre a existência de uma comuna com direito a magistrados judeus, a sinagoga e a cemitério ou a existência de uma rua onde habitava um diminuto grupo de seguidores da Lei de Moisés, comunidade satélite de outra mais importante que se designava por comuna. Por outro lado, estamos convictos de que o aumento populacional na região da Beira interior, tal como no resto do reino, adveio da migração de judeus castelhanos e, também de outros reinos peninsulares como Navarra e Aragão, nos finais dos séculos XIV e XV, crescendo o seu número à medida que nos aproximamos dos finais de Quatrocentos.

Infelizmente, a documentação anterior ao século XV não é muito abundante em informações sobre a maioria da população judaica, residente naquele espaço, com excepção da Guarda, cujas casas da judiaria pertenciam ao rei, e Trancoso pelo poder económico que a comuna detinha no concelho. Mas, se atendermos à documentação real de Duzentos, Trezentos e Quatrocentos, podemos comprovar que a ocupação judaica foi aumentando ao longo dos três últimos séculos da sua presença em território português (Fig. 1).

Apesar da sua menção em documentos de D. Afonso III e de D. Dinis, pudemos verificar a decadência da sua população em algumas destas localidades, de tal maneira que a referência a comuna é praticamente inexistente em finais do século XV, havendo apenas a referência ao pagamento de impostos por judeus ou às rendas da judiaria. Tal aconteceu, por exemplo, em Monforte (da Beira) que, no século XIII e inícios do XIV, parece ter tido uma comunidade pujante. Por outro lado, a documentação confirma-nos que a fixação dos judeus nesta região do interior beirão ocorreu essencialmente entre a segunda metade do século XIV e os finais da primeira metade do XV, assim como a sua dispersão por pequenas localidades aconteceu nos finais desta última centúria.

16 Ferro [Tavares], Os Judeus em Portugal no século XIV (ed. 1970), pp. 20 e 26; Maria José Ferro Tavares, «Judeus e Cristãos-Novos: o ante e pós-baptismo nas terras de Riba Côa e arredores», in O Tratado de Alcanices e a importância histórica das Terras de Riba Côa (Lisboa 1998), pp. 271-272; Rita Costa GoMes, A Guarda medieval: posição, morfologia e sociedade (1200-1500) (Lisboa 1987), pp. 54-58.

17 Ferro [Tavares], Os Judeus em Portugal no século XIV (ed. 1970), pp. 156-160. 


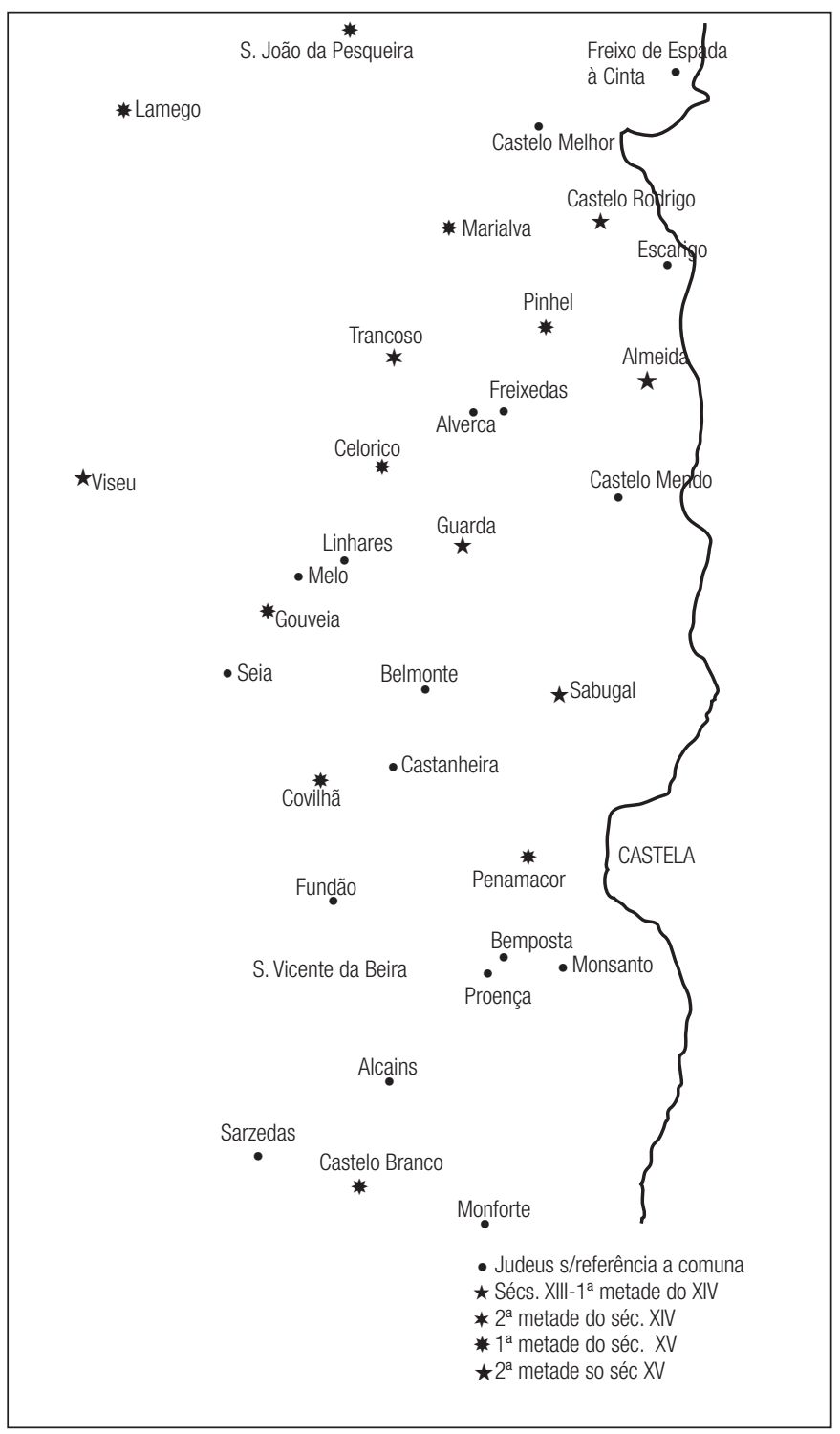

Fig. 1. Comunas e Judiarias da Beira interior

Estas pequenas judiarias seriam, com toda a probabilidade, uma simples rua ou travessa satélite de comunas, integradas em concelhos mais importantes, onde se encontravam as infra-estruturas comunais, ou seja, os magistrados, a sinagoga que funcionava como casa de oração, câmara de vereação, escola e 
tribunal, o cemitério ou adro dos judeus ${ }^{18}$. Tal aconteceria com a judiaria de Alverca, no termo de Trancoso, onde a presença de judeus era já assinalada em finais da primeira metade do século $\mathrm{XV}{ }^{19}$, devido à mudança do campo da feira de Trancoso para este novo espaço, como veremos, e de Freixedas, judiarias satélites da comuna de Trancoso, por exemplo. Provavelmente os judeus de Alverca ter-se-iam deslocado para a vizinha Freixedas, pois encontramos em ambas as localidades indivíduos de apelido Cazez ou Cacez ${ }^{20}$. Exemplo semelhante seria o da judaria de S. Vicente da Beira que estava integrada na comuna de Castelo Branco, segundo o numeramento de $1496{ }^{21}$.

Este documento é muito importante, uma vez que, desde a década de 50 de Quatrocentos, desapareceram as cartas de contrato dadas pelos reis aos judeus, provavelmente, quando atingiam a maioridade e pretendiam exercer uma profissão. Não sendo cartas de privilégio, elas permitiam ao crente na Lei de Moisés, independentemente do género, exercer livremente um ofício e ao mesmo tempo ao monarca colectá-lo pelo seu trabalho. No entanto, a partir da segunda metade do século $X V^{22}$, a permissão para o exercício de um ofício passou a ser dada à comunidade em geral, pelo que nós perdemos um manancial informativo extraordinário. A partir da concessão feita no reinado de D. Afonso V, em 1441 e 1442, aos indivíduos da minoria judaica residentes na Beira interior, podemos concluir que o maior número de cartas outorgado foi atribuído aos judeus residentes em Lamego (75) e na Covilhã (72). Seguiu-se-lhes a Guarda com 62. Em Trancoso e Castelo Branco obtiveram permissão para contratar 44 e 30 judeus, respectivamente. Outras localidades apareciam com um número residual de cartas concedidas ${ }^{23}$.

18 Não é provável que a lápide, encontrada em Belmonte por Samuel Schwarz, tenha pertencido a uma sinagoga ali existente no século XIII. É mais certo que ela tenha sido retirada de um outro local e ali tenha sido guardada e protegida de eventuais destruidores. Aliás, Diaz Esteban coloca muitas reservas à datação de 1297 e propõe uma revisão da mesma (Fernando Díaz Esteban, «Lápidas judias en Portugal», in Estudos Orientais II - O legado cultural de Judeus e Mouros (Lisboa 1991), p. 209). Por outro lado, a mais antiga referência documental à presença judaica em Belmonte pertence à segunda metade do século XV.

19 Maria José Ferro Tavares, Os Judeus em Portugal no século XV (Lisboa 1985), vol. II, p. 10.

20 Tavares, Os Judeus em Portugal no século XV, vol. II, pp. 10 e 135.

21 DiAs, «A Beira interior em 1496», p. 63.

22 Pertence a 1455 a última listagem de cartas de contrato concedidas por $\mathrm{D}$. Afonso $\mathrm{V}$ que chegaram até nós.

23 Além das comunidades acima mencionadas, obtivemos ainda: Alcains e Proença com 1 carta; Castelo Mendo com 2; S. João da Pesqueira com 4; Gouveia com 6, Pinhel com 17, Celorico com 22, Viseu com 23 e Castelo Branco com 30 (Tavares, Os Judeus em Portugal 


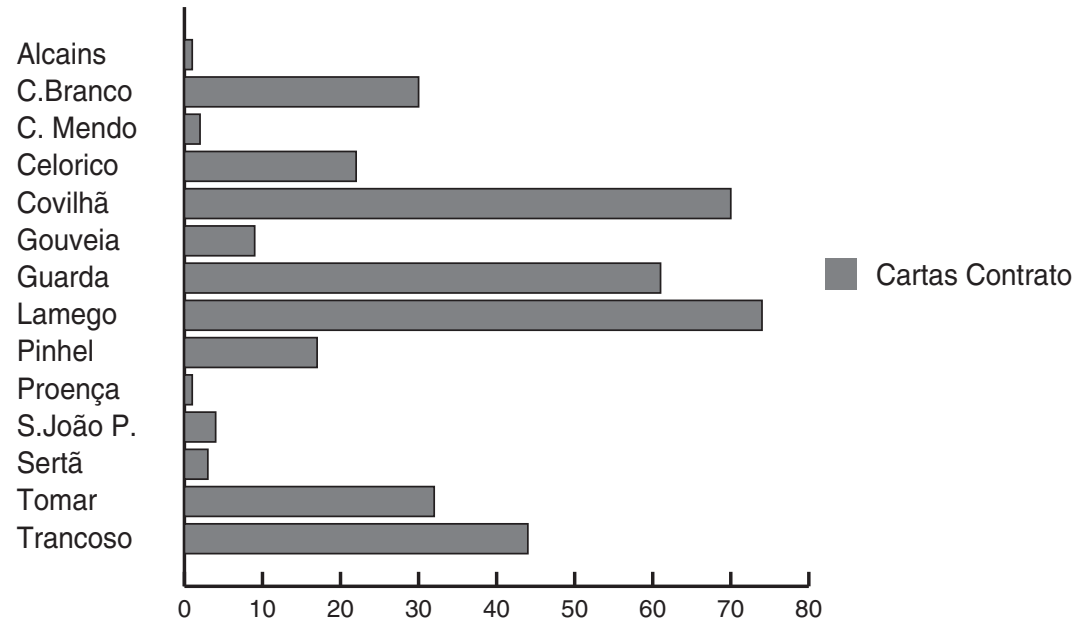

Cartas de contrato concedidas pelo rei a indivíduos judeus, em 1441 e 1442

Os mesmos dados indicam-nos um forte domínio dos artesãos (sapateiros, alfaiates, tecelões e ferreiros), como podemos observar, quer na primeira metade, quer na segunda metade do século XV:

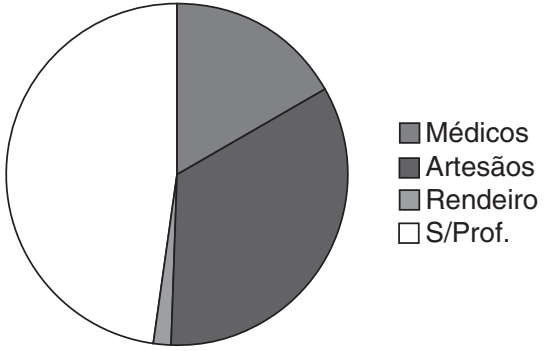

Análise profissional das cartas dadas a judeus da Covilhã em 1441 e 1442

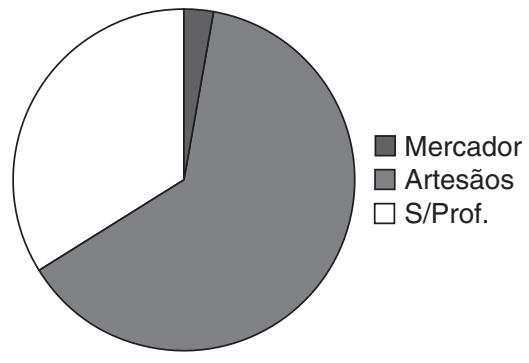

Análise profissional dos judeus da Covilhã na segunda metade do século XV

no século XV, vol. II, pp. 6, 38-39, 44, 46-47, 57-60, 136-137, 145-148, 165-168, 286, 340-341, 374-376, 388-389, 391, 393). 


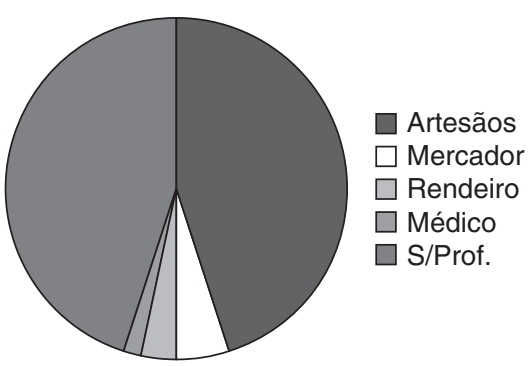

Análise profissional das cartas de contrato outorgadas a judeus da Guarda, em 1441 e 1442

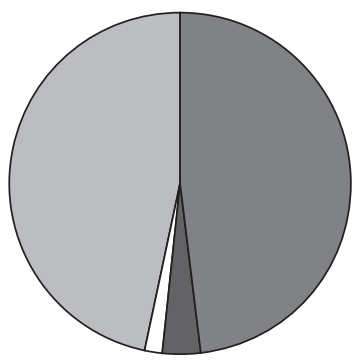

$\square$ Artesãos

$\square$ Mercador $\square$ Médico $\square$ S/Prof.

Análise profissional das cartas de contrato concedidas pelo rei a judeus de Lamego, em 1441 e 1442

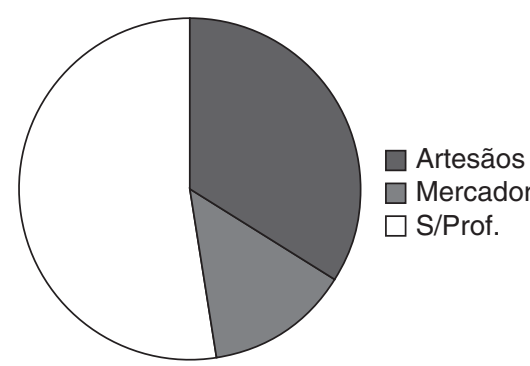

Análise profissional das cartas de contrato concedidas pelo rei a judeus de Trancoso, em 1441 e 1442

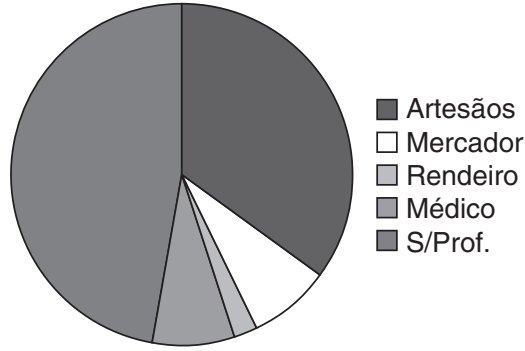

Análise profissional dos judeus da Guarda na segunda metade do século XV

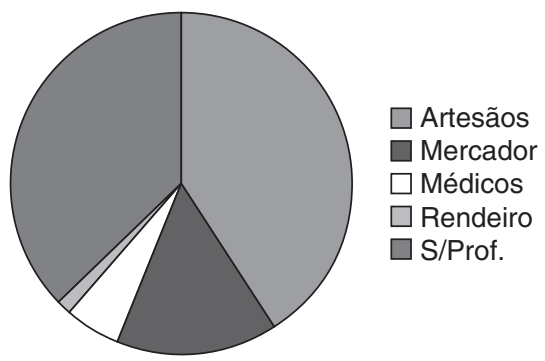

Análise profissional dos judeus de Lamego na segunda metade do século XV

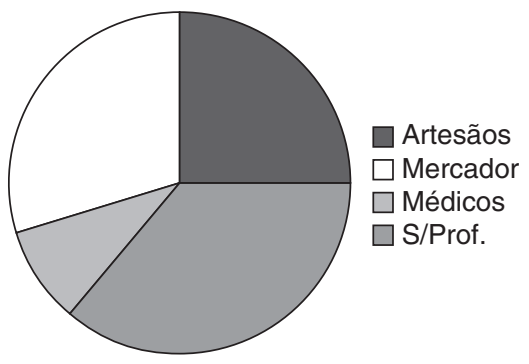

Análise profissional dos judeus de Trancoso na segunda metade do século XV 
Comparando os gráficos, verificamos o predomínio dos artesãos em todas estas comunas e o maior número de mercadores em Trancoso, explicável pela importância da feira de S. Bartolomeu no concelho e na região. Anotamos a existência de ourives, provavelmente uma família originária de Seia, na Covilhã, e de um espingardeiro do rei, em 1492, em Trancoso. Assim, concluímos que a maior parte da população se dedicava ao artesanato, sendo uma minoria a que trabalhava no comércio de panos, nas rendas e na medicina, como físicos e cirurgiões. Não sabemos identificar o ofício daqueles em cuja carta de autorização para contratar estava ausente a profissão, mas podemos, talvez, supor que se trataria de proprietários rurais ou urbanos ou indivíduos que viveriam de rendimentos como o empréstimo de dinheiro ou dos lanços nas rendas reais, municipais ou eclesiásticas sem um ofício definido. Ou seja, como encontraríamos no século seguinte, aqueles que se definiriam por «afazendados», «abastados» ou «que viviam de sua fazenda».

Não podemos esquecer que a região da Beira interior beneficiou da presença da corte dos infantes reais, D. Henrique, filho do rei D. João I, o qual foi primeiro duque de Viseu e senhor da Covilhã, títulos que passariam para o sobrinho D. Fernando, irmão de D. Afonso V, e deste para o duque de Viseu, D. Diogo, irmão da rainha D. Leonor de Lencastre, mulher de D. João II. O exercício da medicina e do comércio de grande trato, provavelmente com Castela e a feira de Medina del Campo, conduziria alguns dos seus habitantes até à família real, como os Goleima de Castelo Branco, Guarda e Covilhã que foram médicos e cirurgiões dos infantes D. Henrique e D. Fernando, tio e sobrinho, duques de Viseu e senhores da Covilhã. Também cirurgião daquele infante foi mestre Jacob, talvez, Jacob Valencim, morador em Lamego, que acumulava com a cirurgia o conhecimento da oftalmologia ${ }^{24}$. A relação de alguns membros destas comunidades com a casa ducal fê-los ascender ao serviço da casa real como mestre José Vizinho, físico e astrólogo de D. João II, natural da Covilhã, como nos indicou João de Barros na sua Década Primeira da Ásia. Outros eram mercadores na corte, como Samuel Benazo, vassalo do rei, residente em Pinhel, ou Judas Valencim, morador em Lamego, ou ainda Samuel Tovi da Guarda, todos eles servidores de D. João II ${ }^{25}$.

As comunidades judaicas da Beira interior cresceram demograficamente ao longo do século $\mathrm{XV}$ e tiveram tendência para aumentar na segunda metade desta centúria. Assim, se contabilizarmos as referências a indivíduos ju-

\footnotetext{
${ }^{24}$ Arquivo Nacional da Torre do Tombo [= TT], Chancelaria de D. Afonso V, liv. 22, fl. 2v; liv. 34, fls. 192v e 193v; liv. 14, fl. 62v; liv. 15, fl. 159; TAvares, Os Judeus em Portugal no século $X V$, vol. II, pp. 42, 60, 152, 168

25 Tavares, Os Judeus em Portugal no século XV, vol. II, pp. 775-777.
} 
deus ao longo das duas metades de Quatrocentos, na documentação régia ${ }^{26}$, a representação gráfica da amostra populacional das comunas é a seguinte:

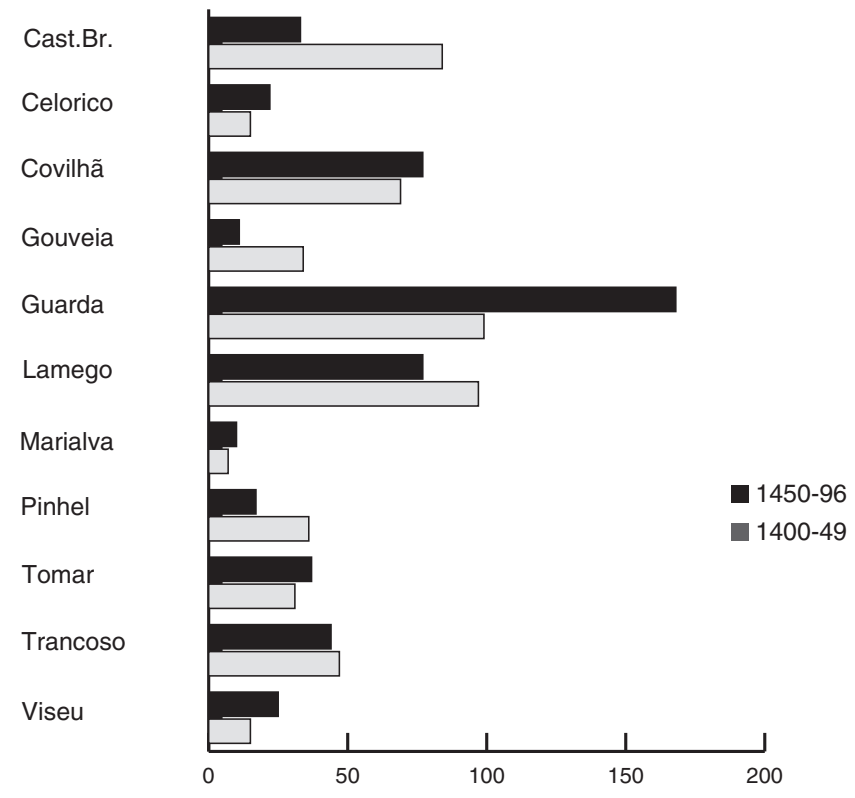

Amostra populacional das comunas da Beira interior (a partir da documentação régia)

Se podemos anotar uma maior densidade populacional na segunda metade do século XV nas comunas acima mencionadas, com excepção da Guarda, onde a queda demográfica foi acentuada, ela torna-se visível nas pequenas comunidades. Assim, Alverca, termo de Trancoso, conhecia 1 judeu sem profissão mencionada, em 1441, e, em 1469, encontramos 6 judeus e correspondentes famílias, quatro deles, sapateiros ${ }^{27}$. Noutras localidades, a presença de judeus respondia às necessidades da população cristã, como, por exemplo, em Alcains, onde encontramos a referência a um Samuel Cide, sapateiro, ou em Lardosa, onde residia um Abraão Tobi, ferreiro, ambos em 1442, ou a uma imigração recente, como em Escarigo, termo de Castelo Rodrigo, onde, em 1491, encontramos como residente Abraão Rua, ou Freixedas, que teria duas famílias a residir na década de $80{ }^{28}$.

\footnotetext{
${ }^{26}$ Acentuo que esta amostra é extraída apenas da documentação da chancelaria régia pelo que o número é-nos dado por defeito, talvez com a única excepção da comuna da Guarda que pertencia ao rei e mereceu uma informação abundante a partir da inquirição da propriedade régia em finais do século XIV (1395), assim como dos contratos de aforamento das casas da judiaria, comum aos vários reinados.

27 Tavares, Os Judeus em Portugal no século XV, vol. II, pp. 391 e 10, respectivamente.

28 Tavares, Os Judeus em Portugal no século XV, vol. II, pp. 6 e 174, 75 e 135, respectivamente.
} 
Se analisarmos o numeramento de 1496, pedido pelo rei D. Manuel, para a região em estudo, verificamos que os oficiais do rei anotaram os concelhos onde não existiam judeus, como em Sortelha, Proença, Alfaiates, Vilar Maior, Castelo Mendo, Castelo Bom, Muxagata, Longroiva e outros onde existia judaria, como Salvaterra ${ }^{29}$. Este documento permite-nos ainda extrair algum termo de comparação entre a percentagem de moradores judeus existente e o número de cristãos num dado concelho, entendendo-se aqui por morador a pessoa do sexo masculino, provavelmente cabeça de família ${ }^{30}$. Assim, na Covilhã foram anotados os seguintes números: 108 seguidores da Lei de Moisés num total de 2334 pessoas aqui residentes, ou seja, aqueles representavam 4,6\% da população do concelho ${ }^{31}$. Número que não se distancia muito do cálculo a partir do pagamento do sisão, onde cada judeu adulto e casado pagava 75,5 reais, pelo que encontramos 73 indivíduos a pagarem imposto, devendo os restantes estarem isentos porque privilegiados.

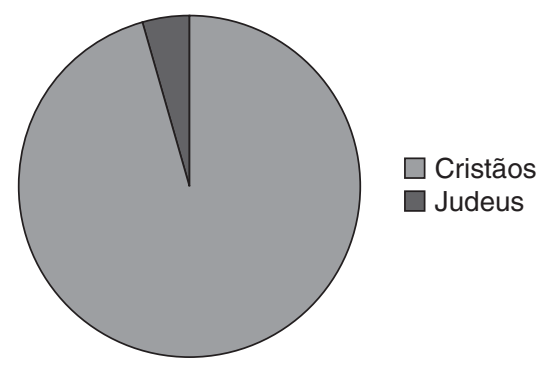

A população da Covilhã em 1496

Por sua vez, com base no pagamento do sisão teríamos em Castelo Rodrigo cerca de 6 judeus adultos e em Trancoso 53, número que nos parece aquém do estimável com base noutras informações documentais. De facto, só pelas cartas de contrato de 1441-42, contabilizámos 44 judeus adultos o que nos permitiria estimar uma população de cerca de 200 pessoas, número que, com toda a pro-

29 DiAs, A Beira interior em 1496, pp. 55, 61, 69, 70, 71, 76, 77 e 59.

30 Diss, A Beira interior em 1496, pp. 43-54. Não há uniformidade por parte dos inquiridores, pelo que podemos entender que o indivíduo do sexo masculino pode corresponder também a um fogo, ou seja, a uma família.

31 DiAs, A Beira interior em 1496, p. 66. Uma vez que os oficiais ora usam a palavra «pessoas», ora «moradores», ora «homens», ora «vizinhos» é possível que estejamos perante o conceito de família e, neste caso, se adoptarmos o coeficiente de 5 pessoas no agregado familiar nuclear poderíamos atingir um máximo de 540 judeus (homens, mulheres e crianças). 
babilidade seria superior em 1496. Assim, e interpretando os 800 moradores com a totalidade dos moradores cristãos e judeus, segundo o numeramento, a percentagem de judeus seria de $25 \%$, aproximadamente ${ }^{32}$.

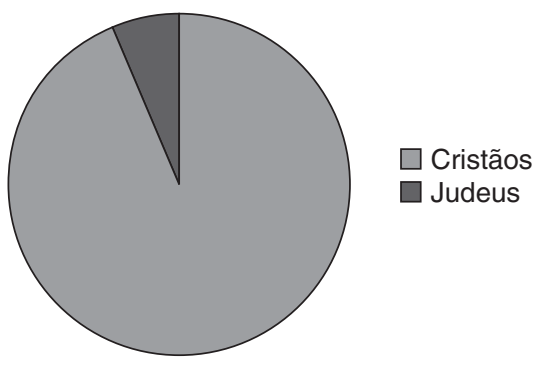

Percentagem de moradores judeus em Trancoso, tomando como base o pagamento do sisão

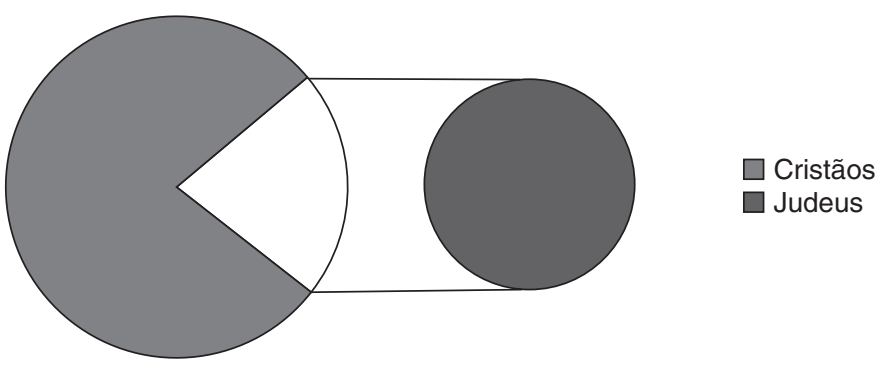

Percentagem de habitantes judaicos em Trancoso

Por outro lado, na Beira interior eram frequentes os apelidos Sacuto, Picorro, Tobi ou Tovi, Amado, Querido, Baruc, Caro, Adida, Mocatel, Rodrigo, Barzelai, etc, ao lado de Cohen, Benjamim e Levi. Por sua vez os apelidos de origem toponímica permitem-nos tirar algumas ilações sobre a mobilidade interna e externa. Assim, judeus originários de Seia radicaram-

32 Tomámos como base para o cálculo, a documentação da chancelaria régia que nos permite estimar estarmos em presença de uma população que oscilaria entre as 200 e 300 pessoas. Em 1441-42, a partir das cartas de contrato, encontrámos a menção de 44 judeus adultos que poderiam corresponder, ou não, a outras tantas famílias. Se multiplicarmos este número pelo coeficiente 5 , dar-nos-ia cerca de 220 pessoas, no mínimo, pois pudemos verificar que as famílias cristãs novas iriam ser constituídas por um elevado número de filhos que atingia a idade adulta e, por vezes, ultrapassava a dezena. 
se na Covilhã, enquanto outros, provenientes de Leiria, foram residir para Castelo Branco e Guarda, outros de Pinhel ou de Linhares deslocaram-se para a Guarda. Mas não só, para a Beira interior vieram judeus da Navarra, abundando os apelidos Navarro nos mais importantes concelhos da região, assim como de Leão, de Castela, a que se seguiam os relacionados com as cidades como Estela, Carmona, Barcelona, San Felices, Cáceres, Calahorra, Valença, Sória, Toledo, etc.

Por sua vez, ao analisarmos o mapa da Figura 1 não podemos deixar de confirmar a tendência para a fixação da população judaica junto à Raia com Castela, o que facilitava as relações comerciais, por vezes clandestinas de ambos os lados da fronteira, mas também familiares.

O documento de 1496, que temos vindo a referir, permite-nos obter, igualmente, algumas informações sobre os impostos pagos pelos judeus da região:

\begin{tabular}{|c|c|}
\hline JUDARIA/COMUNA & IMPOSTO/ANO \\
\hline Judaria de Monsanto & Sisa judenga (rei?) -4000 reais \\
\hline Judaria de Salvaterra & $\begin{array}{l}\text { Sisa judenga e direitos reais (conde de Monsanto) } \\
-1500 \text { reais }\end{array}$ \\
\hline $\begin{array}{l}\text { Comuna de Castelo Branco e judaria } \\
\text { de S. Vicente da Beira }\end{array}$ & Direitos reais (rei?) -23000 reais \\
\hline Covilhã & $\begin{array}{l}\text { Sisa judenga (D. Rodrigo de Castro, alcaide) - } \\
40000 \text { reais } \\
\text { Sisão (conde de Abranches) }-5500 \text { reais } \\
\text { Ferreiros de Ceuta (rei) }-600 \text { reais }\end{array}$ \\
\hline Judaria de Belmonte & $\begin{array}{l}\text { Sisa judenga (João Fernandes Cabral, alcaide) - } \\
400 \text { reais }\end{array}$ \\
\hline Judaria de Sabugal & Sisa judenga - ? \\
\hline Judaria de Almeida & (rei) - ? \\
\hline Judaria de Pinhel & (Marechal do reino) - ? ${ }^{33}$ \\
\hline Judaria de Castelo Rodrigo & $\begin{array}{l}\text { Sisa judenga (rei) }-7000 \text { reais } \\
\text { Sisão (conde de Abranches) }-400 \text { reais }\end{array}$ \\
\hline Judaria de Castelo Melhor e Almendra & $?^{34}$ \\
\hline Judaria de Marialva & Sisa judenga (rei) - ? \\
\hline
\end{tabular}

33 O Marechal do reino, D. Fernando Coutinho, recebia 70000 reais dos direitos reais, portagem e rendas da judaria de Pinhel. 
JUDARIA/COMUNA

\begin{tabular}{ll}
\hline Comuna de Trancoso & Sisa judenga e genesim (rei) - ? \\
& Sisão (conde de Abranches) -4000 reais \\
& Ferreiros de Ceuta (rei) - > 700 reais \\
\hline Judaria de Celorico & Sisa judenga (D. Diogo de Meneses) - \\
& 10000 reais \\
\hline Judaria da Guarda & Direitos reais e sisa judenga (João de Sousa) \\
& -20000 reais \\
\hline Judaria de Linhares & $?^{35}$ \\
\hline
\end{tabular}

Desconhecemos o valor global dos tributos pagos ao rei pelas comunidades da Beira interior, uma vez que a informação é incompleta e a mais conhecida é a parcela doada em tença aos fidalgos e que D. Manuel foi obrigado a indemnizar quando expulsou as gentes da minoria do reino. Assim, os Castro e os Coutinho eram os detentores de uma parcela das rendas, embora o quantitativo recebido devesse ficar aquém da realidade fiscal paga pelas comunas ao rei, se juntarmos ao pagamento das tenças a informação acima apresentada.

$\begin{array}{lll}\text { Concessionário } & \text { Comuna(s) } & \text { TenÇa(s) }\end{array}$

\begin{tabular}{|c|c|c|}
\hline $\begin{array}{l}\text { Conde de Portalegre, } \\
\text { D. Diogo da Silva Meneses }\end{array}$ & Celorico & ? \\
\hline D. Álvaro de Castro & Lamego & 55000 reais \\
\hline D. Rodrigo de Castro & Covilhã & 42500 reais \\
\hline D. Diogo de Castro & $\begin{array}{l}\text { Sabugal, Trancoso e } \\
\text { Marialva }\end{array}$ & 40720 reais \\
\hline $\begin{array}{l}\text { D. Fernando Coutinho, } \\
\text { marechal do reino }\end{array}$ & Pinhel & 20000 reais \\
\hline Francisco da Silveira & Sarzedas & 20000 reais \\
\hline $\begin{array}{l}\text { D. Francisco Coutinho, } \\
\text { conde de Marialva } \\
\text { e de Loulé }\end{array}$ & Castelo Rodrigo & 20000 reais \\
\hline
\end{tabular}

\footnotetext{
${ }^{34}$ A sisa judenga encontra-se incluída entre outros tributos que somam 600 reais

${ }^{35}$ A sisa judenga encontra-se agregada à portagem, foros e maninhos, valendo 19000 reais. Para toda a informação: DiAs, A Beira interior em 1496, pp. 11-102, nomeadamente pp. 55-91.
} 


\begin{tabular}{llc}
\multicolumn{1}{c}{ Concessionário } & \multicolumn{1}{c}{ Comuna(s) } & TenÇa(s) \\
\hline João de Sousa & Guarda & 20000 reais \\
\hline Pedro de Andrade & Viseu & 14000 reais \\
\hline D. Mécia de Melo & $\begin{array}{l}\text { Bemposta e Freixo } \\
\text { de Espada à Cinta }\end{array}$ & 600 reais \\
\hline D. Joana de Castro & Monsanto & 5760 reais $^{36}$ \\
\hline
\end{tabular}

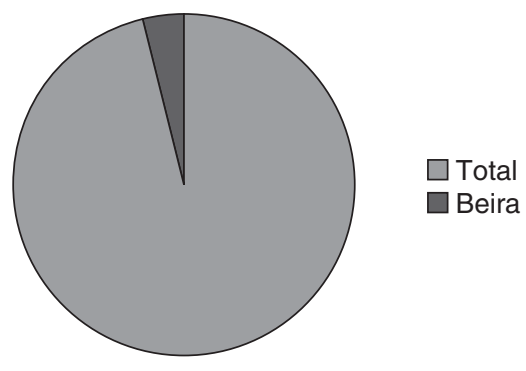

Perventagem das rendas das comunas e judarias da Beira interior no total do reino

\section{A COMUna de Trancoso, o ÉDito de EXPULS̃̃o E o BAPTISMO FORÇADO}

Com existência documentada em meados do século XIV, encontramos a comuna de Trancoso, que nos surge mencionada nas cartas régias de D. Pedro I com alguma notoriedade, o que nos faz pensar que a sua origem seja anterior, uma vez que o rei afirmava precisamente que a judiaria se reduzia a uma rua «em que sempre viverom que he na metade da dicta villa» ${ }^{37}$. De facto, a sua existência e importância apareciam directamente associadas à feira franca da vila, a qual foi criada por D. Afonso III, pelo que podemos supor que a origem da comunidade seria contemporânea da acima mencionada. Sabemos que a conhecida feira de S. Bartolomeu, que tinha como núcleo a semana em que ocorria a celebração deste santo padroeiro, 24 de Agosto, durava cerca de três semanas, quinze dias de feira e oito dias antes para a chegada e acolhimento dos merca-

${ }^{36}$ Tavares, Os Judeus em Portugal no século XV, vol. II, pp. 763-768. A tença do conde de Portalegre incluía as rendas das judiarias de Celorico e de Portalegre (Alentejo), no valor total de 71066 reais e 7 pretos.

37 Chancelarias Portuguesas. D. Pedro I (1357-1367), ed. Antonio Henrique de OliveIRA Marques (Lisboa 1984), p. 457; Ferro [TAVAres], Os judeus em Portugal no século XIV, p. 27. 
dores. Com D. Dinis, o concelho obteve a permissão para ter feiras mensais, no início da quarta semana de cada mês, a qual tinha a duração de três dias ${ }^{38}$.

A sua importância para a região esteve bem patente na documentação de Trezentos e de Quatrocentos. Virgínia Rau escreveu a este respeito:

A sua influência [da feira] nas relações económicas da região fez-se sentir numa área bastante grande. Era nela que o cabido da Sé de Viseu conseguia arrendar mais vantajosamente as suas propriedades, e que Castelo Branco vendia os gados da sua criação, factos que demonstram a amplitude da esfera de acção desse centro de traficância, nos fins do século XIV e princípios do século $\mathrm{XV}^{39}$.

Ora, esta actividade económica era motivo de deslocação de pessoas de estratos sociais elevados, leigas e clericais, ao concelho e, por isso, motor de desenvolvimento de Trancoso e do seu termo. Assim, não podemos estranhar que ela estivesse directamente relacionada com a presença da comunidade judaica, que, na centúria de Trezentos, tinha a sua judaria localizada intra-muros e porventura numa das zonas mais importantes do espaço municipal e de maior proximidade com o chão da feira, junto à porta d'el-rei, pelo menos assim a encontramos na segunda metade do séc. XIV. No entanto, ainda no reinado de D. Afonso IV (1359), encontramos um judeu, Moisés Adida, a residir na Rua da Carniçaria, à porta do Carvalho ${ }^{40}$, ou seja, no sentido oposto ao da porta d'el-rei e do chão da feira.

A 15 de Setembro de 1364, a comuna, alegando que obtivera recentemente judiaria apartada, solicitava e ganhava de D. Pedro I a isenção do direito de aposentadoria a nobres, oficiais régios e outras dignidades que visitassem o concelho. No entanto, este recusava-se a cumprir a carta de privilégio outorgada pelo soberano e continuava a exigir-lhes o direito, incluindo a ocupação de suas casas. Queixavam-se os judeus de que, no tempo da feira, os corregedores e os seus oficiais se instalavam nas suas habitações, fazendo-lhes perder o lucro que auferiam com o aluguer das mesmas aos mercadores e visitantes que se deslocavam à feira, o qual era, naquela altura, igual ao que retiravam no resto do ano. Atento ao agravo da comuna que, obviamente, se repercutia nos impostos que recebia, D. Pedro I ratificava a anterior carta de privilégio, estendendo a isenção aos infantes e seus oficiais, aos corregedores e outros oficiais da justiça, assim como a quaisquer poderosos ${ }^{41}$.

\footnotetext{
38 Virgínia Rau, Feiras medievais portuguesas. Subsídios para o seu estudo (Lisboa 1983, $2^{\mathrm{a}}$ ed.), pp. 85-86.

39 RaU, Feiras medievais portuguesas, pp. 86-87.

40 Viseu, Arquivo Distrital, Cabido da Sé, maço 38, no 39.

41 Chancelarias... D. Pedro I, pp. 433-434; Ferro [Tavares], Os judeus em Portugal no
} 
No entanto, a 1 de Fevereiro do ano seguinte, o monarca revogaria o privilégio concedido à comuna de judeus. Se excluirmos, na carta de privilégio ao concelho de Trancoso, datada deste dia e ano, uma certa rivalidade existente entre a maioria cristã e a minoria judaica, podemos anotar o seguinte: Trancoso possuía uma comuna com rabi, entidade com quem os juízes do concelho dialogavam para o cumprimento do direito da aposentadoria; a judaria era uma rua que ficava na «metade da dicta villa» e fora-lhes dada recentemente como judaria apartada; os judeus eram «muitos» e «muito ricos».

Nas entrelinhas, podemos ver que os agravos do concelho contra a comuna assentavam no facto de esta, alegando ter tido judiaria apartada recentemente, ter beneficiado da isenção de aposentadoria, o que obviamente iria prejudicar a comunidade cristã sobre a qual passara a recair a totalidade do serviço. Curiosamente, a irritação de D. Pedro I, ao revogar a carta de graça dada aos judeus da vila, residiu no facto de ter havido um acordo prévio entre o concelho e a comuna, acordo que fora escondido, voluntariamente ou não, pelos representantes dos judeus, e que muito provavelmente se baseava no seguinte: os judeus continuavam a residir na rua onde sempre tinham habitado, rua que pertencia ao concelho e onde eles viveriam misturados com os cristãos, no início. Para não serem desalojados dessa rua, os judeus teriam aceite ficar com o encargo da aposentadoria, passando a rua a ser «judaria apartada agora novamente», ou seja, havia pouco tempo. Dela tinham sido excluídos os moradores cristãos ${ }^{42}$.

Ora, onde se localizava o bairro ou a rua dos judeus de Trancoso? Em 1997, escrevi o seguinte a propósito da sua localização:

Documentos relativos aos processos de cristãos novos deste concelho na Inquisição permitem-nos localizar a judiaria perto da Corredoura, onde terminava uma parte. Seria chamada Vila Nova e daria o nome à igreja que lhe estava próxima, S. João de Vila Nova. Ao bairro dos judeus deve ter pertencido a Rua Direita, paralela à Corredoura e que ia desembocar na praça, próximo das igrejas de S. Tiago, de Sta. Maria de Guimarães e de S. Pedro, ou seja, na zona destruída para construção do recente edifício da câmara ${ }^{43}$.

século XIV, pp. 203-204.

42 Chancelarias... D. Pedro I, p. 457: «E que ora quando eu fuy em essa comarca os dictos judeus vieram a mjm dizer que o concelho lhe dera judaria apartada agora nouamente pella qual razam lhes eu dey mjnha carta de graça per que lhes nom tomasem roupa nem galinhas nem pousasem com elles Calando em ello os dictos judeus a uerdade da dicta razam porque a elles foy dada por judaria a Rua em que sempre viuerom que he na metade da dicta villa [...]».

${ }^{43}$ Tavares, «Judeus e Cristãos-Novos: o ante e pós baptismo nas Terras de Riba Côa e 
Temos consciência de que esta nossa afirmação vai contra o que é voz corrente em Trancoso, que a coloca para os lados da porta de S. João, e cuja origem documentada desconhecemos. No entanto, procurando perceber a razão desta tradição, lemos com atenção o livro Notícias de Trancoso de Lopes Correia, autor que a transmite: «Do lado nascente não há nem nunca houve igrejas e isto, em nossa opinião, por ser a judiaria» ${ }^{44}$. Ora, nada mais erróneo. As judiarias, em todo o mundo cristão, tiveram sempre igrejas nas proximidades, pois um dos objectivos da tolerância religiosa era a conversão voluntária dos judeus ao cristianismo e esta era incentivada pela apologética pregada no púlpito das igrejas ou no seu adro.

No entanto, este autor esteve muito próximo da sua verdadeira localização, ao mencionar a Rua Nova, ou seja, a antiga rua da judaria que, com o baptismo forçado dos judeus, se tornou a rua nova da cristandade. No entanto, em finais do século XV, a judiaria devia ter sido constituída por outras ruas ou travessas, formando um bairro, que viria a ser referido por Vila Nova, após a expulsão. A igreja de S. João, hoje destruída, e frequentada pelos cristãos novos da vila, devia ter sido a antiga sinagoga, que fora alargada no tempo de D. João II ${ }^{45}$, tornada templo cristão como tantas outras e local preferencial, para alguns deles se fazerem sepultar em terra virgem.

A corroborar a nossa hipótese de localização da judaria, junto à porta d'El-rei e entre esta e a porta do Prado, estão as informações dos processos da Inquisição e, talvez, a descrição que o abade de Nossa Senhora da Fresta faz destas duas portas, que as tornam únicas em relação às outras duas portas da vila. De facto, ambas têm «dois andares de portas de pau» e «junto a primeira porta de pau quando se entra para a villa desce encaixada em huma e outra torre huma forte grade de pau, de que se não uza por não ser necessário». Acrescentava o nosso autor que a porta do Prado, igual à d'el-rei, tinha à direita de quem entrava um grande poço ${ }^{46}$. As outras duas portas, a do Carvalho e a de S. João, não aparecem assim descritas. Ora esta referência a portas duplas, sendo uma delas uma grade que se descia, leva-nos a supor que ambas definiam o espaço do bairro dos judeus, o que é corroborado pelo facto de as primeiras gerações de cristãos novos aparecerem associadas, pelo local de residência, à rua da Corredoura e às freguesias de S. Tiago, S. João de Vila Nova ou S. João de intra-muros, e mais raramente S. Pedro.

arredores», p. 273.

44 Joaquim Manuel Lopes Correia, Notícias de Trancoso (Trancoso 1986), p. 47.

45 TT, Chancelaria de D. João II, liv. 2, fl. 131.

${ }^{46}$ TT, Dicionário Geográfico, vol. 43, pp. 412-413. 
Isto significa que, tal como a documentação do século XIV nos fazia supor, a judiaria de Trancoso situava-se no exterior da cerca velha ${ }^{47}$, na proximidade do chão da feira, mas no interior das muralhas erguidas ao longo de Trezentos e que viria a ser a zona mais rica e importante do concelho, nos séculos seguintes, junto à porta d'El-rei e da Corredoura. Este espaço, no interior das muralhas de Trezentos, ocuparia cerca de $1 / 4$ da área exterior à cerca velha, provavelmente vazio ou pouco habitado na altura em que os judeus começaram a residir nele e que nos parece consentâneo com o cálculo populacional acima apresentado, assim como com a designação de «Vila Nova» dada ao bairro dos judeus, após a expulsão e o baptismo forçado. Infelizmente as casas não pertenciam ao monarca como acontecia na Guarda, pelo que a sua localização não nos está perfeitamente delimitada no espaço municipal, espaço que, hoje, se encontra também adulterado em relação ao seu passado. Talvez fossem propriedade da comuna, dos judeus, do concelho ou das igrejas da vila, ou de todos eles, uma vez que os judeus em Portugal puderam usufruir do direito de adquirir solo urbano e outros bens de raiz.

Consultando o Dicionário Geográfico, verificamos que o abade de Nossa Senhora da Fresta referia, em 1732, a existência de três feiras em Trancoso: a feira de S. Bartolomeu, ou feira franca, no chão junto à porta d'el-rei, estendendo-se por toda a Corredoura e terreiro da igreja de S. João, a mais antiga e que nos interessa, neste momento, a de Sta. Luzia e a feira junto a Nossa Senhora da Fresta ${ }^{48}$.

Para além da feira franca e da feira mensal, Trancoso tinha ainda o mercado semanal que vinha a perder frequentadores, devido aos mercados mensais realizados em concelhos próximos como Celorico, Aguiar da Beira, Pinhel, Guarda,

47 Ainda hoje é visível uns restos da cerca velha no interior do centro urbano, acompanhando a actual Rua de João Abel, antiga Rua dos Cavaleiros, e que terminaria na desaparecida porta de S. João (Júlio Rocha de Sousa, Antiga vila de Trancoso, Viseu 2004, pp. 38 e 39). A actual muralha é do século XIV e já existia no tempo de D. Pedro I, tendo sido iniciada provavelmente por D. Dinis. A comprová-lo está a referência documental à localização da judaria e o escudo sobre a porta da muralha, explicando-se a sua necessidade não só por razões de defesa, mas pelo crescimento populacional provocado pela feira franca. Oliveira Marques escreveu o seguinte, a propósito das muralhas de Trezentos: «Uma das provas de crescimento urbano foi a construção de novas cintas de muralhas abarcando espaços muito mais amplos do que os contidos na primitiva cerca. Todo o século XIV testemunhou esse facto, mormente a partir do reinado de D. Afonso IV. As novas áreas amuralhadas não correspondiam sempre a um surto urbano proporcional. Por vezes, planeava-se a construção da cerca prevendo um crescimento futuro» (A. H. de OliveIRA Marques, Portugal na crise dos séculos XIV e XV, in Nova História de Portugal, dir. Joel SerRão e A. H. de Oliveira Marques, Lisboa 1987, vol. IV, p. 182).

48 TT, Dicionário Geográfico, vol. 43, p. 417. 
etc. É nesta relação de Trancoso com a sua feira ou feiras que devemos entender o crescimento da comuna e dos seus bairros: o mais antigo, em Trancoso, e o mais pequeno, satélite da comuna, em Alverca ${ }^{49}$, em meados de Quatrocentos e que se estenderia a Freixedas, como já referimos.

É provável que a riqueza, que a comunidade retirava do aluguer das casas aos mercadores e visitantes, tivesse diminuído com as restrições ao relacionamento entre cristãos e judeus, imposto pelos primeiros reis da dinastia de Avis, pois o concelho queixava-se a D. João I, em 1407, que a nobreza procurava a aposentadoria nas aldeias dos arredores com prejuízo da autarquia, que não alugava as suas casas, e dos moradores destas que viam as searas e as vinhas destruídas. Ainda, em 1459, a feira era bastante frequentada, apesar de o concelho nas cortes referir a sua decadência. Dos sete capítulos das cortes de Lisboa deste ano, apresentados por Trancoso, seis relacionavam-se com a feira, o que mostra a impacto que esta tinha na economia do município.

Nos agravos, associavam a decadência da feira aos arrendamentos das sisas, não indicando se os rendeiros eram judeus ou cristãos ${ }^{50}$, os quais cometiam opressões e agravos sobre os mercadores. Noutro artigo, queixavam-se contra a mudança do local da feira e da exposição das mercadorias, a que atribuíam o desinteresse de alguns mercadores pela feira de Trancoso. De facto, a feira, que se realizava à porta d'el-rei e intra-muros, era prejudicada pela ausência de um bom regimento para a aposentadoria de todos quantos a ela se dirigiam. Talvez, por isso, ela fora transferida para Alverca, no termo de Trancoso ${ }^{51}$.

Por esta altura, as comunidades judaicas de Trancoso e da Guarda mantinham uma rivalidade, que residia no facto de esta última ser a cabeça do almoxarifado da Beira, cabendo-lhe, por isso, a responsabilidade da repartição dos impostos pelas demais comunas da região. Mais antiga e localizada numa sede de bispado, a comuna da Guarda, decadente em meados de Quatrocentos, continuava a deter o poder de eleger entre os seus membros o repartidor dos impostos, agregando a este um representante de outra comunidade do mesmo almoxarifado. Os dois oficiais determinavam em conjunto quanto cabia na globalidade e per capita a cada comuna ou judaria, sem previamente a ouvirem. Contra este

49 TT, Chancelaria de D. Afonso V, liv. 31, fls. $25 \mathrm{v}^{\circ}$ e $32 v^{\circ}$; TAVAres, Os judeus em Portugal no século $\mathrm{XV}, \mathrm{p} .45$.

${ }^{50}$ Aliás, em 1454, os rendeiros da sisa eram dois judeus, Jacob Castelão e Jacob Soleima, e um cristão, Álvaro Martins da Covilhã (RAU, Feiras medievais portuguesas, p. 89).

${ }^{51}$ RAU, Feiras medievais portuguesas, pp. 89-90. Os agravos do concelho apresentados nas cortes de Lisboa de 1459 mencionavam a feira mudada «per aluerca» já em 1454, o que deve ter acontecido em finais da década de Quarenta ou inícios de Cinquenta. 
facto insurgiram-se os judeus de Trancoso, em plena pujança económica, que pediram e obtiveram de $\mathrm{D}$. Afonso $\mathrm{V}$ a permissão para um seu procurador estar presente na referida repartição ${ }^{52}$.

O prestígio crescente da comunidade, e que era visível no espaço concelhio que ocupava, estava relacionado com o estatuto sócio-económico da sua população. Pudemos observar que a comunidade foi alargando o número daqueles que se intitulavam mercadores e que podemos associar ao comércio por grosso, geralmente de panos, panos que eram vendidos na feira, mas que também eram expostos, consoante o regimento municipal, no exterior das lojas em expositores sob as arcadas, ou não, de uma rua Direita ou de uma praça, praça que ainda em pleno século XVIII era descrita com os seus balcões cobertos de mercadorias diversas e abundantes. Directamente associados ao comércio dos tecidos estavam os ofícios que os transformavam como alfaiates e gibiteiros. Outros mesteres que se prendiam com o trabalho das peles, numa região onde a criação de gado era já mencionada, eram os dos sapateiros e pergaminheiros. A comunidade tinha ainda, em finais de Quatrocentos, um físico, mestre José Levi, que acumulou com as funções de rabi, um mestre Isaac Fabibe, cirurgião, e um mestre Salomão Cidecairo, físico.

Apesar da riqueza, os judeus de Trancoso não foram bafejados pelos privilégios reais, talvez por se encontrarem longe dos locais preferidos pela corte, e o concelho pertencer ao rei. No entanto, alguns conseguiram receber cartas de privilégio. Assim aconteceu com David Borcas ou Bacoa, servidor de D. Gonçalo Coutinho, alcaide de Trancoso, o atrás mencionado mestre José, físico, e Salomão Canês, espingardeiro do rei ${ }^{53}$. Bacoa recebeu carta de privilégio que o dispensava do exercício de cargos comunais, enquanto mestre José obtinha a permissão para se deslocar em besta muar de sela e freio e, por fim, Salomão Canês, o privilégio de espingardeiro do rei ${ }^{54}$.

A comuna tinha os seus magistrados próprios. Os rabis como o físico mestre José Levi, um escrivão, como Haim Franco, ou o escrivão da câmara, sisão e genesim, como Moisés Rodriga foram alguns dos nomes que chegaram até nós ${ }^{55}$. Os oficiais judeus eram obrigados, desde finais do século XIV, a dominar o português escrito, pois as chancelarias comunais deixaram de ser redigidas em

52 Maria José Ferro Tavares, Os judeus em Portugal no século XV (Lisboa 1981), p. 195; EAD., «Os Judeus e Cristãos Novos: ante e pós baptismo nas Terras de Riba Côa», p. 273.

53 Tavares, Os Judeus em Portugal no século XV, vol. II, pp. 374-378.

54 Tavares, Os Judeus em Portugal no século XV, vol. II, pp. 787 (1450, 31/03), 795 (1465, 18/02), 807 (1492. 29/03).

55 Tavares, Os Judeus em Portugal no século XV, vol. II, pp. 376 e 378. 
hebraico. Como nem todos escreviam o português, havia cristãos que desempenhavam cargos na comuna como o tabelião João Afonso ou Fernão Álvares, escudeiro, ou Álvaro Peres, escrivão da sisa judenga paga na feira de S. Bartolomeu, desde 1473 a 1496, acumulando, neste último ano, com a escrivaninha dos direitos reais dos judeus de Trancoso ${ }^{56}$. Em meados do século XV, a comuna teve os seus rabis eleitos, em vez de nomeados pelo rei, a título perpétuo. Tal privilégio teve a intercessão junto de D. Afonso V de Lopo de Albuquerque, camareiro do rei, o mesmo fidalgo que, a partir de 1 de Janeiro de 1465, passaria a receber como rendimento os serviços real e novo dos judeus de Trancoso ${ }^{57}$.

Não podemos comprovar que a expulsão dos judeus de Castela, em Março de 1492, pelos Reis Católicos tenha tido como consequência o aumento da população judaica do concelho, embora pensemos que tal viria a acontecer, à semelhança de outros locais do reino, nem tão pouco que os recém-vindos tenham contribuído para o renascimento económico do município, pelo menos, até à data da sua expulsão do reino por D. Manuel.

Em 4 ou 5 de Dezembro de 1496, este monarca promulgava o édito de expulsão das minorias judaica e muçulmana do reino. À semelhança do que aconteceu noutros lugares, os oficiais do rei leram o édito nos paços do concelho, perante as autoridades municipais e da comuna, e, em seguida, foramno ler na sinagoga a toda a população judaica, a qual se preparou para partir, cumprindo a vontade do rei ${ }^{58}$. Sabemos, também, que a maioria não o fez, sendo forçada a receber o baptismo nas igrejas de Trancoso ou de outros concelhos do reino, depois de lhes terem retirado as crianças até dois anos de idade, a 19 de Março de 1497, sábado de Ramos, porventura a Páscoa judaica. Baptizados à força, os adultos receberiam as águas do baptismo nas igrejas do concelho para onde foram conduzidos ${ }^{59}$. A maioria permaneceria no município devido às restrições à mobilidade para que não abandonassem o reino nem vendessem os bens ${ }^{60}$.

56 Tavares, Os Judeus em Portugal no século XV, vol. II, pp. 695-709.

${ }^{57}$ TT, Chancelaria de D. Afonso V, liv. 8, fl 175.

${ }^{58}$ Conhecemos os passos dados, diríamos o «ritual» da leitura e da aceitação por parte da comunidade judaica através dos seus rabis, pela documentação inédita encontrada no concelho de Loulé e que foi objecto de duas comunicações que ainda aguardam publicação pela Câmara Municipal deste concelho. No entanto, esta informação foi por nós utilizada no livro de nossa autoria, A herança judaica em Portugal (Lisboa 2004).

59 Alguns receberam o baptismo na igreja de S. João de Vila Nova o que nos faz supor que a sinagoga foi de imediato transformada em templo cristão.

${ }^{60}$ Maria José Ferro Tavares, Judaísmo e Inquisição. Estudos (Lisboa 1987), pp. 17-66. 
Uma minoria recebê-lo-ia voluntariamente pelo que, se pertencente à elite judaica, obteria uma carta de limpeza de sangue e, por privilégio real, entraria na pequena nobreza. Tal deve ter sucedido com João Rodrigues Ferro, judeu castelhano, natural de San Felices, que pediu para receber o baptismo e ascendeu a escudeiro, estatuto em que seria confirmado pela propriedade da quinta da Ribeira de Távora ${ }^{61}$.

Outros, já baptizados, chegariam a Trancoso depois de uma peregrinação por outros lugares do reino. Assim aconteceu com André Gonçalves, sapateiro, também ele natural de San Felices, que foi baptizado de pé em Sanfins da Marinha, perto do Porto, tendo como padrinhos todos os fregueses da localidade que estiveram presentes ao seu baptismo ${ }^{62}$. No entanto, após o baptismo, a catequização não foi muito convincente, embora a maioria dos cristãos novos de Trancoso soubesse persignar-se e recitar as orações principais, como o Pai Nosso, a Ave Maria, o Credo, em latim ou em português, e com mais dificuldade a Salve Rainha.

Ana Rodrigues, natural de Medina del Campo, fora baptizada em S. João de Vila Nova pelo abade Álvaro Saraiva e crismada na igreja de S. Pedro ${ }^{63}$. Por sua vez, Francisco do Vale recebera as águas do baptismo, sendo criança, na igreja de S. Pedro ${ }^{64}$. Beatriz Rodrigues fora baptizada quando D. Manuel mandara tirar os meninos aos judeus. Tinha dez anos de idade ${ }^{65}$.

Baptizados livremente ou à força, os cristãos novos mantiveram a sua residência preferencial na judaria, que passou a ser habitada também por cristãos velhos, quando aqueles, depois do levantamento contra os cristãos novos de Lisboa, em Abril de 1506, passaram a poder sair do reino ou a deslocar-se para outros lugares onde o seu passado de judeus não era conhecido, quer no interior de Portugal, quer no seu império. Com a mobilidade veio também a deslocação para outros espaços no interior do concelho, outrora exclusivamente habitados por cristãos, como a Praça, a Rua de S. Pedro, a Rua da Cadeia, etc. Baptizados, podiam receber ordens religiosas, mandar os filhos para a Universidade ou participar na vida municipal, como magistrados, ou ser membros de confrarias e da Misericórdia. O nome já não os distinguia, excepto na comunidade onde os conhece-

\footnotetext{
${ }^{61}$ TT, Inquisição de Évora, no 3738.

${ }^{62} \mathrm{TT}$, Inquisição de Évora, $\mathrm{n}^{\circ} 7512$.

${ }_{63} \mathrm{TT}$, Inquisição de Évora, $\mathrm{n}^{\circ} 8918$.

${ }^{64} \mathrm{TT}$, Inquisição de Évora, $\mathrm{n}^{\circ} 7896$.

65 TT, Inquisição de Évora, no 2431.
} 
ra judeus, em que, por vezes, o nome judaico permanecia como alcunha, como acontecia com Manuel Rodrigues, o Baruc ${ }^{66}$. Apesar de proibido o casamento entre cristãos novos, este foi mantido como regra, sendo o casamento misto uma excepção nas primeiras gerações. E o mesmo viria a acontecer com as sociedades comerciais que criavam, que mais não eram senão o prolongamento das relações familiares, onde os cristãos velhos não entravam.

\section{A COMUNIDADE CRISTÃ NOVA E A ENTRADA DA INQUISIÇÃo EM TRANCOSO}

Não há dúvida que Trancoso mereceu logo no início o interesse dos inquiridores, porque o concelho tinha fortes relações com a raia castelhana e, sobretudo, porque nele se localizou um dos mais importantes focos de irradiação do messianismo judaico, fortalecido pelas trovas de cariz milenarista do sapateiro de Trancoso, Gonçalo Eanes, o Bandarra ${ }^{67}$. Aliás, era «pública voz e fama» que os cristãos novos da vila eram maus cristãos, como pudemos ler em muitos depoimentos a eles relativos, dados por escravas, criadas cristãs velhas, religiosos e cidadãos da vila, como Simão Luís, tabelião, António Benevides, abade de S. Tiago, António Carvalho, arcipreste, António Saraiva, juiz dos órfãos, Fernão Lopes Saraiva, escudeiro fidalgo, Gonçalo Anes, sapateiro, quem sabe se o nosso Bandarra, assim como nos autos da inquirição realizados pelo bacharel Jorge Gonçalves Ribeiro e pelo licenciado Gregório Martins Caminha, juiz de fora em Trancoso, em 1547. Aliás, um desses testemunhos, o de João Pires, tosador, morador na rua Direita de Trancoso onde tinha tenda aberta, afirmava claramente que aos sábados, na Rua Direita, onde residiam quase todos os cristãos novos,

\footnotetext{
${ }^{66}$ Pai de António Rodrigues, genro de André Gonçalves de Trancoso (TT, Inquisição de Évora, $\mathrm{n}^{\circ} 7512$ ).

${ }^{67}$ Sobre este assunto e sobre a influência do Bandarra na comunidade cristã nova, veja-se: Maria José Ferro TAVAres, «Para o estudo dos judeus de Trás-os-Montes, no século XVI: a $1^{\text {a }}$ geração de cristãos novos», Revista Cultura História e Filosofia 4 (1985), pp. 371-417; EAD., Judaísmo e Inquisição (Lisboa 1987); EAD., «Características do messianismo judaico em Portugal», in Estudos Orientais II - O legado cultural de Judeus e Mouros (Lisboa 1991), pp. 245-266; EAD., Los Judios en Portugal (Madrid 1992), pp. 187-259. Estes trabalhos e outros resultaram de uma investigação conjunta, financiada pela Fundação Gulbenkian, e dirigida por mim com a participação de Lucília Runa e Maria do Carmo Teixeira Pinto, como bolseiras deste projecto de investigação, as quais levantaram os processos da Inquisição de Évora, entre 1540-47. Mais recentemente e utilizando muita informação dos trabalhos então publicados, Elias LiPINER, Gonçalo Anes Bandarra e os cristãosnovos (Trancoso 1996). Sobre a influência do Bandarra no sebastianismo, pode-se consultar o clássico de J. Lúcio de Azevedo, A evolução do Sebastianismo (Lisboa 1928).
} 
as portas das suas casas e das lojas não se abriam tão cedo e, quando se abriam, era para as cristãs novas se visitarem umas às outras.

Os testemunhos dos cristãos velhos eram corroborados, segundo escrevia o inquisidor Pedro Álvares de Paredes, pelo depoimento do cristão novo André Gonçalves que afirmava

[...] que os christãos novos desa villa sam maos christãos e que guardam os sabados e os solenizam como os judeus faziam e lhes via comecarem a guarda-llos da sesta feira a tarde, comecando a llympar suas casas e nos mesmos sabados se vestiam de vestidos melhorados dos que trazem pellos outros dias da semana e se visitam huns a outros especiallmente as mulheres christãs novas e outras muitas coussas [...].

Acrescentava que sabia tudo isto de o ver, de o ouvir e de o saber, porque lho diziam. Para confirmar a veracidade do seu testemunho remetia para o tabelião Simão Luís, cristão velho, que de tudo sabia. Este confirmava a suspeita existente entre os cristãos velhos, chamando a atenção para os ajuntamentos que faziam em casa uns dos outros, nomeadamente quando um deles falecia, impedindo a presença dos cristãos velhos até o defunto ter sido sepultado, pelo que todos desconfiavam que mantinham o ritual da morte à maneira judaica, o que era alicerçado pela procura constante de covas virgens; para os pretextos de doença ao sábado, o que era entendido como uma maneira de continuarem a guardar o descanso sabático.

Simão Luís acabaria por indicar os nomes de outras pessoas que, por trabalharem em casa de cristãos novos, poderiam dar mais informações, não sem deixar de acusar de cerimónias judaicas a João da Fonseca, tabelião como ele. Não seria o único cristão novo a ser denunciado. Outros se lhe seguiram como mestre Jerónimo, já falecido, e sua filha Isabel Dias, Manuel Carlos, Beatriz Gonçalves, a «nariguda», Isabel Dias, a parteira, a sogra de Jorge Dias, Isabel Lopes, a «papeira», mãe de Manuel Fernandes, sapateiro, Beatriz Pinheira, Lucrécia Nunes, Violante Henriques, Isabel de Almeida, Simão Gomes, tabelião, e a mulher, Isabel Lopes, a «menoa», o licenciado Manuel Henriques, filho de Jorge Henriques, e a mulher, a mulher de João da Fonseca, António Ferraz e a sua mãe, Filipa Mendes, Mécia do Vale, etc, etc. Nestas denúncias Manuel Carlos aparecia como um dos rabis que doutrinava o grupo, lendo por um livro e usando tafilis, enquanto André, António e Duarte Gonçalves eram identificados como os coveiros dos cristãos novos ${ }^{68}$.

${ }_{68} \mathrm{TT}$, Inquisição de Évora, no 11567 (auto da diligência feita em Trancoso); nº 9890, fls. 79-90v. Simão Luís, no seu depoimento, desfiava uma lista de nomes de pessoas, muitas delas, 
Mas não eram só os cristãos velhos os grandes denunciantes. A maioria das suspeitas fora corroborada por alguns cristãos novos da comunidade, tais como os sapateiros André Gonçalves, António Gonçalves e Duarte Gonçalves, pai e filho e primo de ambos, respectivamente, que acusariam mais de cinquenta famílias de judaizarem ${ }^{69}$. Quem eram, como viviam e a que actividades económicas se dedicavam estes cristãos novos, é o que tentaremos retratar, em síntese, a partir do quotidiano denunciado nos processos da Inquisição ${ }^{70}$.

Pudemos confirmar que estes descendentes de judeus em primeira, segunda e terceira geração de cristãos mantinham entre si uma feroz endogamia, casando com outros cristãos novos da mesma ou de comunidades vizinhas, onde se salientavam Guarda, Pinhel, Celorico, Valverde nos arredores de Aguiar da Beira, Sabugal, Melo, Penamacor, Fundão, ou mais distantes como Montemor-o-Novo, Bragança, por exemplo. Tais casamentos eram suspeitos pelo que houvera uma devassa contra os cristãos novos da região, encabeçada pelo corregedor Martim Velho ${ }^{71}$.

Os processos da Inquisição de Évora, iniciados pouco depois do estabelecimento do Tribunal do Santo Ofício, mostram-nos uma comunidade próspera, onde o cristianismo escondia um judaísmo clandestino no interior das casas. A visitação dos inquisidores provocou um despovoamento quase geral no concelho, de tal modo que, no parecer que os representantes dos cristãos novos deram a D. João III, declaravam que o inquisidor «fez fogir em dous ou três dias cento e satenta moradores que os mais delles herão merquadores riquos» ${ }^{72}$. Aliás, a lista de cristãos novos fugitivos e para quem existia mandado de captura no reino ou em Espanha era grande. Em Castelo Rodrigo ou em San Felices de los Gallegos deviam ter-se acolhido Jorge Rodrigues, Francisco Dias e Henrique Lopes. Em Almendra, junto à Raia, esconderam-se numa quinta Isabel Rodrigues, mulher de Simão Peixoto, e a filha de ambos. Para San Felices partiram os irmãos Francisco Dias, Jorge Mendes e Nuno Dias, Leonor Mendes, mulher de José Francisco,

presas no Sto. Ofício de Évora, que eram associadas a estas práticas: Duarte Gonçalves, André Gonçalves, António Gonçalves, filho deste último,

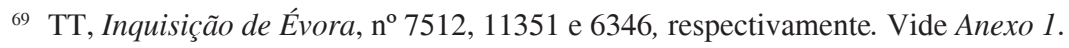

${ }^{70}$ Esperamos vir a escrever um trabalho de maior fôlego sobre os cristãos novos de Trancoso, estendendo-o às suas relações com outras comunidades da Beira interior, assim como à sua diáspora.

${ }^{71} \mathrm{TT}$, Inquisição de Évora, $\mathrm{n}^{\circ} 9890$.

72 As Gavetas da Torre do Tombo (Lisboa 1960), vol. I, pp. 38 e 232-234; TAVARES, Judaísmo e Inquisição, p. 92; EAD., Los Judios en Portugal, p. 189. 
Bernardo Ferro e a sua mulher Catarina Soares, o licenciado Nuno Dias, etc. Em Cidade Rodrigo, deviam ter-se refugiado Francisco Lopes, «o portageiro», Luís Feijó, «o velho», e sua mulher, seu sobrinho Luís Feijó, «o pequenino», Clara Rodrigues, irmã de um dos Luís Feijó, Francisco Lopes, o do forno, Francisco Lopes e sua filha, Manuel Pinheiro e sua mulher Maria da Fonseca, Diogo Pinheiro e seu irmão Simão Pinheiro, banqueiro, Manuel Carlos e sua mulher Catarina (?) Soares, António João e sua mulher Ana Rodrigues. Para Medina del Rio Seco tinham partido mestre António e sua mulher ${ }^{73}$, e muitos outros para locais desconhecidos.

A tentativa de fuga seria uma das acusações feitas contra alguns dos ricos cristãos novos do concelho, como Francisco Carlos, mercador, acusado de ter dado ordem para vender os bens aos familiares, com o objectivo de estes partirem do reino. Preso enviara uma carta ao filho, ordenando-lhe que vendesse a «mercadoria», o que levou os familiares, que ainda se encontravam livres e na vila, a entender que ele confessara e indirectamente lhes estava a indicar que fugissem, o que acabariam por fazer Manuel Carlos, Branca Carlos e outros cristãos novos ${ }^{74}$. Alguns, apesar de se encontrarem fora do reino, não conseguiram escapar aos braços inquisitoriais, como aconteceu com o rico mercador Diogo Pinheiro que, tendo-se refugiado em Espanha, foi preso em Cidade Rodrigo pela inquisição de Llerena que desconfiara da entrada de tantos portugueses no reino. Viria a ser denunciado à inquisição de Llerena, por correspondência enviada pelo inquisidor de Évora ${ }^{75}$.

A mobilidade era uma constante no interior do reino ou do outro lado da fronteira, onde alguns se fixavam quer como mercadores, quer como médicos. Francisco Carlos deslocava-se com frequência a Quintela de Lampaços, a Bornes, a Bragança ou a Lisboa, ou a Cidade Rodrigo, onde apanhara peste. Justificava as deslocações por razões de negócios; para os seus denunciantes, era uma maneira de divulgar a religião judaica, junto das comunidades cristãs novas. Tal acontecera quando era rendeiro dos votos de Sambade, onde pousara na casa de Álvaro de Leão de Cortiços e de sua mulher Leonor de Carvajal, o qual, com seu irmão Jorge de Leão, tinham as rendas do arcebispado de Braga, em que ele próprio, Francisco Carlos, tinha parceria, pelo que costumava ir arrecadar a renda com os dois irmãos ${ }^{76}$.

${ }^{73} \mathrm{TT}$, Inquisição de Évora, ${ }^{\circ} 6346$.

74 TT, Inquisição de Évora, $\mathrm{n}^{\circ} 9890$.

75 TT, Inquisição de Évora, $\mathrm{n}^{\circ} 8122$.

${ }^{76} \mathrm{TT}$, Inquisição de Évora, no 9890. 
Por sua vez, mestre Manuel, cirurgião, viera para Trancoso por ter casado com Lucrécia Nunes que aqui vivera com sua mãe, natural de Pinhel. Conhecera-a em Évora, onde residiam os irmãos e de Évora fora morar em Portel e daqui para Lisboa, onde casou, antes de partir para Trancoso ${ }^{77}$. O bacharel em leis, Diogo de Solazar, natural da Guarda, fora casar a Trancoso e partira para Cidade Rodrigo, onde vivia com a família ${ }^{78}$. Também Simão Rodrigues, lavrador e criador de gado, natural da Guarda, viera residir em Trancoso e aqui casara o filho mais velho ${ }^{79}$. O mesmo aconteceria com Ana Antónia que se consorciara em Trancoso com Manuel Fernandes, mercador e tratante, apesar de ter nascido em Coimbra e a sua família ser originária da Covilhã ${ }^{80}$.

Este relacionamento fechado, quer familiar, quer económico, permitiu-lhes viver numa atitude híbrida: exteriormente cristãos, baptizados, crismados e frequentadores da igreja e dos sacramentos, membros de confrarias, e, ao mesmo tempo, continuadores da tradição religiosa judaica no interior das suas famílias e casas.

Se as mulheres mantinham o ritual que lhes pertenceu sempre, como a limpeza da casa, a mudança de roupa da cama e a preparação da refeição do sábado à sexta-feira, a limpeza da candeia com a colocação de matula nova e de azeite, deixando-a acesa num quarto ou numa arca, durante toda a noite de sexta para sábado, a limpeza da casa para a preparação da Páscoa do pão ázimo, o fabrico deste e a sua distribuição clandestina por algumas delas junto das famílias cristãs novas, aos homens cabia a degolação dos animais, a indicação dos dias certos em que caiam as Páscoas judaicas e os jejuns, nomeadamente o quipur e o da rainha Ester, indicação que procuravam no Sidur, livro que alguns ainda possuíam clandestinamente. A prática do descanso sabático, das festas judaicas, como a Páscoa do cordeiro, o Pentecostes e a das cabanas, dias em que se enfeitavam e vestiam melhor, os jejuns à maneira judaica de dia inteiro até ao aparecimento da «estrela», os thanis de segunda e quintafeira, a recusa em comer carne de porco ou sangue, os peixes sem escamas, ou seja, os alimentos proibidos na Lei de Moisés, a cozedura dos pães ázimos com os bolos de azeite no forno de Francisco Lopes, forneiro, cristão novo de Trancoso, eram outras das denúncias feitas, quer por cristãos velhos, quer por cristãos novos.

77 TT, Inquisição de Évora, $\mathrm{n}^{\circ} 11285$ e $\mathrm{n}^{\circ} 8632$.

78 TT, Inquisição de Évora, $\mathrm{n}^{\circ} 11285$

79 TT, Inquisição de Coimbra, $\mathrm{n}^{\circ} 923$.

${ }_{80} \mathrm{TT}$, Inquisição de Coimbra, $\mathrm{n}^{\circ} 924$. 
Manuel Carlos, os Gonçalves e alguns mais eram acusados de prepararem os corpos dos defuntos cristãos novos à maneira judaica: aos homens cabia o amortalhamento com as mãos ao longo do corpo e os pés paralelos e não, à maneira cristã com as mãos e os pés cruzados, a lavagem do morto com água perfumada, o corte das unhas das mãos e dos pés, assim como o corte da barba e outros pelos do corpo, vestirem-no com roupa nova e mortalha nunca usada nem lavada e procurarem uma sepultura em terra virgem. Às mulheres pertencia o pranto dos mortos, mas também a lavagem do corpo com água perfumada. A estas também competia despejar toda a água existente na casa ou nas casas próximas, pois acreditavam que o anjo da morte e a alma do morto lá tinham mergulhado.

Alguns ainda recordavam as orações, muitas vezes extraídas dos Salmos mas sem a recitação no final da Glória. Rezavam cabeceando, de mãos abertas e afastadas uma da outra, voltados para a janela ou para uma parede e olhos erguidos para o céu. Invocavam o Deus de Abraão, de Isaac e de Jacob. Deitavam a bênção fazendo correr as mãos pelo rosto.

Entre eles estava divulgada a crença messiânica, a qual se arreigara com a divulgação e interpretação das trovas do Bandarra. Acreditavam que estaria para breve a vinda do Messias dos judeus, vendo nos acontecimentos ${ }^{81}$ da época sinais confirmativos de que estavam a viver anos messiânicos. A vinda de David Reubeni ao reino e a sua presença em Almeirim, onde estava a corte, reforçou a crença dos cristãos novos de que o Messias dos judeus, que os havia de conduzir a Jerusalém, estaria para breve. Aliás, com o objectivo de obter informações a este respeito, João Rodrigues Ferro, de Trancoso, deslocou-se a Lisboa para falar com o filho do rei dos judeus, o denominado «judeu do sapato», que vinha a Portugal como embaixador em nome de seu irmão. Nas denúncias constava esta deslocação de João Rodrigues a Almeirim, segundo uns, para levar os presentes que os cristãos novos de Trancoso ofereceram a Reubeni.

Na denúncia que fez de Francisco de Valladolid, preso em Espanha, João Rodrigues Ferro declarou que o Messias dos judeus era o Anticristo dos cristãos, segundo umas trovas que circulavam, com toda a probabilidade as do Bandarra, que falavam das tribos perdidas de Israel e do seu capitão pertencente à tribo de Dan o qual devia vir pelo ano de $1550{ }^{82}$. Também Lucrécia Nunes (Ouro,

81 Nomeadamente a invasão de Roma pelo rei de França e pelo imperador Carlos V, o cerco que os turcos estavam a fazer à cristandade com o avanço por terra para o interior da Europa e pelo Mediterrâneo, por exemplo (TAVARES, «Características do messianismo judaico em Portugal», pp. 245-266; EAD., Los Judios en Portugal, pp. 187-259).

82 TT, Inquisição de Évora, no 3738 . Era homem de 80 anos, natural de San Felices de los 
nome judaico) ${ }^{83}$ se referia ao Bandarra como alguém que sabia muito acerca do Messias dos judeus e das tribos perdidas de Israel. Aludia ao Messias, chamando-lhe «meu bem» e acreditava que a sua vinda estaria para breve, para o ano de 1548, e os havia de conduzir à Terra Prometida. Mesmo presa continuava a jejuar e a rezar à maneira judaica, ensinando a algumas das prisioneiras orações que aprendera com a mãe, ex-Lia ou «Lea», quando era criança. Elogiava os que tinham conseguido partir para o Golfo ou para a Flandres onde se encontrava uma «Benveniste» numa alusão clara a Beatriz de Luna ou Gracia Mendes, que ajudava os cristãos novos pobres na fuga ${ }^{84}$.

A deslocação a feiras, como a de Sta. Eufémia, em Setembro, era pretexto para os jejuns, como o do quipur, que caia por esta altura, ou um passeio pelo campo, com saída e entrada pela porta de S. João, transformava-se no cumprimento do descanso sabático, sob a alegação de afazeres fora da vila. No caso das mulheres, a ida ao mercado, na Praça, com as suas escravas que, depois das compras mandavam para casa, enquanto elas ficavam a conversar o dia todo umas com as outras, passeando pela Praça e pela Corredoura, era o pretexto para a prática do descanso sabático sem que os cristãos velhos desconfiassem. Nos Ramos, festejavam a Páscoa judaica, e no domingo de Páscoa, confraternizavam com os cristãos a Páscoa cristã. Pelo Natal, iam buscar água à fonte e lançavam nela um ferro em brasa e às vezes também vinho. Nas Páscoas de Setembro ( $h a-$ nuca) e na dos Ramos (a Pessah), comiam em louça nova, e alguns acendiam a menorah de sete braços, segundo testemunhava a escrava Antónia. Festejavam o Pentecostes e o ros hashanah. Jejuavam o thisabeat, os thanis de segunda e quinta-feira, o yom quipur, o purim da rainha Ester sempre à maneira judaica, ou seja, até ao cair da noite. Rezavam cabeceando como os judeus e alguns faziamno ainda em hebraico, segundo os denunciantes ${ }^{85}$.

Alguns cristãos novos tinham fama de serem rabis, como Francisco e Manuel Carlos, que seriam acusados de amortalhar os correligionários falecidos à maneira judaica, de degolar os animais e cobrir o sangue com terra, de conhecer os dias dos jejuns dos judeus, como o quipur, indicando-os a outros e jejuando-os à maneira judaica, durante o dia todo até a noite cair, de saber orações judaicas,

Gallegos. A mulher chamara-se Paloma.

83 Os nomes judaicos aparecem com duas vertentes: de alcunha, pela memória da família entre os vizinhos cristãos velhos ou um nome clandestino, interno à família, enquanto para a sociedade predominava o nome cristão do baptismo. Seria o caso de Lucrécia, pois nascera já após o baptismo forçado.

${ }^{84} \mathrm{TT}$, Inquisição de Évora, $\mathrm{n}^{\circ} 8632$.

85 TT, Inquisição de Évora, ${ }^{\circ}$ 8355, 7512. 
de usar tafilis e de possuir livros proibidos, além de se vangloriar de ser filho de rabi Iça (Joshua) Cohen ${ }^{86}$.

Também o licenciado João Luís Medina seria alvo da mesma acusação e de ter sepultado o pai junto aos degraus da porta da igreja de S. Pedro que fora aberta recentemente para a travessa de S. Pedro, por ser terra virgem ${ }^{87}$. Não eram os únicos. Isabel de Almeida acusaria Duarte Lopes, o «nevoeiro», e Manuel Carlos de serem «sabidos na Lei» e de lhe indicarem os jejuns e as festas judaicas para ela as guardar ${ }^{88}$.

Algumas das casas de cristãos novos funcionavam como oratorio, pois nelas se reuniam grupos pequenos para rezar e ouvir os «clérigos dos judeus», ou seja, os rabis. A reunião era feita numa câmara no piso superior, por vezes, numa câmara interior, para que olhos indiscretos não vissem e não fossem denunciar. No entanto, com pouco sucesso, pois as visitas de vários cristãos novos a outro ou outra cristã nova, mesmo com o pretexto de que estes últimos se encontravam doentes, eram alvo de suspeita por parte dos vizinhos cristãos velhos ou da criadagem, sobretudo se a visita coincidia com um sábado ou com a proximidade da Páscoa. Uma destas «sinagogas» era na casa de Manuel Carlos, irmão de Francisco Carlos, onde se juntavam aos sábados alguns dos seus familiares, como os casais Pedro Henriques e Ana Rodrigues, o mercador e siseiro Simão Garcia e Isabel do Vale, Jácome Rodrigues Beselga e Brites Rodrigues, os Feijó, Catarina Rodrigues, a dona da casa e irmã destas, assim como a mãe Mécia do Vale, sogra de Manuel Carlos ${ }^{89}$.

Alguns membros da comunidade detinham uma cultura e um estatuto social comuns a uma burguesia média ou alta com a qual se relacionavam. Mestre Manuel, cirurgião, possuía em casa livros de medicina, sendo acusado de ter livros dos judeus que quis esconder junto do arcipreste, que se recusou a recebêlos porque os achou suspeitos ${ }^{90}$. Por sua vez o licenciado João Luís Medina tinha em casa livros de quiromância e o Antigo e o Novo Testamento glosados por Nicolau de Lira ${ }^{91}$. Francisco Carlos possuía livros em sua casa, incluindo a História do Palmeirim, uma Torah, segundo alguns, que ele declarava ser uma Bíblia e outros livros ${ }^{92}$. Sabia música, tocava órgão e cantava cantochão.

\footnotetext{
86 TT, Inquisição de Évora, $\mathrm{n}^{\circ} 9890$.

87 TT, Inquisição de Évora, $\mathrm{n}^{\circ} 5305$.

$88 \mathrm{TT}$, Inquisição de Évora, $\mathrm{n}^{\circ} 8355$.

89 TT, Inquisição de Évora, $\mathrm{n}^{\circ} 7512$.

90 TT, Inquisição de Évora, $\mathrm{n}^{\mathrm{o}} 11285$.

91 TT, Inquisição de Évora, $\mathrm{n}^{\circ} 5305$.

92 TT, Inquisição de Évora, no 9890.
} 
A cultura mostrava que Francisco Carlos era uma pessoa educada, educação que lhe advinha da riqueza que herdara e que o integrava na elite de Trancoso. Para além de investir nas rendas, Francisco Carlos era mercador de panos de lã de Castela e da Flandres, tendo loja aberta. O seu estatuto social era visível nas relações matrimoniais que estabelecia para os filhos, assim como no seu relacionamento com a elite cristã velha, que visitava e com quem se distraía, jogando às cartas. A filha mais velha, Branca casara-se com um cristão novo de Trancoso, Diogo Soares, que era criado do infante D. Luís, filho de D. Manuel. Por sua vez, estava relacionado por afinidade, por via de Maria Draga, sua mulher, com João Rodrigues Ferro, escudeiro, casado com Isabel Lopes que era tia materna da sua mulher, e com os Pinheiro, família de mercadores e banqueiro, sendo Manuel Pinheiro primo segundo co-irmão de Francisco Carlos.

No auto da sua prisão em Trancoso, o tabelião descreveu o seu vestuário e penteado, tanto mais que ele declarara ter tomado ordens, o que o tabelião duvidara porque não lhe vira sinais de tonsura na cabeça. O corte do cabelo era redondo até às orelhas. $\mathrm{Na}$ cabeça usava um barretinho preto redondo e trazia vestido um pelote preto comprido até aos joelhos, de mangas direitas. Trazia vestidas umas calças brancas e umas botas brancas com o carnaz virado.

Francisco Carlos era tido por rabi ou capelão dos cristãos novos de Trancoso, como já o fora dos cristãos novos de Trás-os-Montes, quando aqui vivera. Era acusado de participar no amortalhamento ao modo judaico dos cristãos novos defuntos da vila, como o pai, mestre Carlos, Jorge Henriques ou Francisco Rodrigues. Preso na cadeia da vila, Francisco Carlos, «porque era pessoa de qualidade», aceitara pagar a um homem de confiança, nomeado pelo juiz de Trancoso, que o acompanhasse até à prisão da Inquisição em Évora, depois de o ter recusado fazer, alegando que não tinha bens para tal. $\mathrm{O}$ meirinho André Gil foi indigitado para o acompanhar preso a Évora. Perante as acusações, protestava ser fiel cristão, baptizado na igreja de S. Pedro e freguês da igreja de S. João. Comprovava-o com o facto de estar bem doutrinado, auxiliar e cantar nas missas e pertencer a diversas confrarias como a do Santíssimo Sacramento, Nossa Senhora do Rosário, do Espírito Santo e outras. Estávamos em 1543 e permaneceria na cadeia até 1549 , tendo abjurado na sé de Évora, graças à bula do perdão concedida por Paulo III aos cristãos novos portugueses ${ }^{93}$.

Acompanhara-o na prisão em Évora, a mulher Maria Draga, filha de Fernão Drago, lavrador, residente em Valverde, termo de Aguiar da Beira, mas natural de Vinhais, em Trás-os-Montes, que viera casar a Trancoso. O

${ }_{93} \mathrm{TT}$, Inquisição de Évora, no 9890. 
pai juntava a agricultura com as rendas. A mãe, Filipa Rodrigues, era irmã de Jorge Rodrigues, mercador, casado com Isabel Rodrigues, e, também, de Isabel Lopes, mulher de João Rodrigues Ferro, e de Filipa Lopes. Maria Draga tinha uma irmã casada com Francisco Martins, tabelião, que residia em Vilar Maior.

Começou por negar as acusações de práticas judaicas, justificando o seu desconhecimento da religião judaica, porque havia muitos anos que não existiam judeus em Portugal e os pais residiam numa aldeia, entre lavradores cristãos velhos, sendo o pai um lavrador como estes. Depois de casada, residira em Bornes, em Trás-os-Montes, acompanhando o marido que era rendeiro, antes de vir morar definitivamente em Trancoso de onde o marido era natural. Tal como o marido apresentava certidões de pertença a confrarias da igreja de S. João de Vila Nova, em Trancoso, de que era freguesa, e sabia as orações e demais doutrina cristã que começara a ensinar aos filhos de seis e sete anos.

$\mathrm{Na}$ Inquisição, seria ainda acusada de ter tentado subornar os carcereiros e de ter judaizado com outras presas no mesmo cárcere ${ }^{94}$.

João (ex-José) Rodrigues Ferro era um ancião de 80 anos quando foi preso. Natural de San Felices de los Gallegos converteu-se ao cristianismo de livre vontade, em 1492, tendo sido baptizado em Pinhel e tido como padrinho o Marechal do rei, D Fernando Coutinho. Era escudeiro, proprietário da quinta da Ribeira de Távora. Tinha dois filhos vivos: Guiomar Lopes, casada em Bragança com o memposteiro, e Fernão Ferro ou Fernão Lopes Ferro, casado em Trancoso com Filipa Rodrigues, filha de Francisco Rodrigues, tabelião. Uma sua irmã fora viver para Lisboa. Sabia hebraico e orações em hebraico, entre as quais a Shema Israel, que ensinava a outros cristãos novos. Acreditava que a vinda do Messias estaria para breve, no que perseverou depois da vinda de David Reubeni ao reino e divulgava-a junto de cristãos novos castelhanos, como Francisco de Valladolid. Em Trancoso era tido por um dos «clérigos» dos cristãos novos e a sua casa por «sinagoga». Viria a morrer no cárcere, pelo que os netos se apresentaram para defender a honra do avô ${ }^{95}$.

Parente, talvez cunhada, de João Rodrigues Ferro era Filipa Lopes, com cerca de 80 anos de idade, casada em Bragança, com Bernardo Lopes, escudeiro e afilhado do rei D. Manuel. O pai, Henrique Nogueira, mercador, era natural de Trancoso e a mãe de Bragança. Ambos já tinham falecido e estavam enterrados em S. João de Vila Nova. O mesmo acontecera com irmãos e outros familiares. Apenas tinha dois

\footnotetext{
94 TT, Inquisição de Évora, $\mathrm{n}^{\mathrm{o}} 7491$.

95 TT, Inquisição de Évora, $\mathrm{n}^{\mathrm{o}} 3738$.
} 
sobrinhos: Guiomar Lopes ${ }^{96}$, casada em segundas núpcias com Francisco Barroso, memposteiro de Bragança, e Bernardo Lopes. Apresentava-se mal catequizada, apenas sabendo o Pai Nosso e não conhecendo nenhuma outra oração cristã. Negava a ressurreição e que Cristo era o Messias prometido. Afirmava que ainda estava para vir o «Rabi Iça que é Senhor» e quando ele viesse toda a riqueza do mundo seria dada aos cristãos novos. Recusava jurar sobre os Evangelhos.

Fora baptizada e crismada em Bragança e, em Trancoso, era freguesa de S. João de Vila Nova, pertencendo à confraria do Santíssimo Sacramento desta igreja. Confessaria as práticas judaicas de que era acusada, enquanto viveu em Bragança, para beneficiar do perdão geral ${ }^{97}$.

A anciã Ana Rodrigues, natural de Medina del Campo, era viúva do tabelião e mercador Francisco Rodrigues. Pelo casamento dos filhos estava ligada às famílias cristãs novas gradas de Trancoso e provenientes de Castela. Assim, o filho mais velho, Jorge Francisco, mercador, casara-se com Isabel Pinheira, filha de Diogo Pinheiro. A filha, Isabel Rodrigues fora casar à Covilhã com o rendeiro Simão Peixoto. Duas outras filhas, Catarina Soares e Filipa Rodrigues ligaram-se pelo matrimónio aos dois filhos de João Rodrigues Ferro, ambos mercadores. Era tia do licenciado João Luís Medina ${ }^{98}$.

André Gonçalves, sapateiro, era natural de San Felices de los Gallegos. Entrara em Portugal quando do êxodo dos judeus castelhanos, em 1492, e fora baptizado, ainda adolescente, em Sanfins, bispado do Porto, numa cerimónia colectiva pelo que foram os fregueses desta paróquia os seus padrinhos. Era filho de Manuel Rodrigues, de alcunha o Baruc. Estava casado com Ana Fernandes de quem tinha 11 filhos, dois rapazes e nove meninas. Os filhos adultos eram sapateiros como o pai e viviam casados em Trancoso. A filha mais velha casara e regressara a Castela, residindo em Placencia.

Residia na freguesia de S. João, cuja igreja frequentava, confessando-se ao pároco nas alturas devidas. Soube persignar-se e dizer as orações, ora em português, ora em latim, embora se tivesse enganado em algumas partes da SalveRainha, que disse em latim. Foi acusado, tal como viria a sê-lo o filho António e o primo Duarte Gonçalves, de ser coveiro e o degolador dos animais, cuja carne

${ }^{96}$ Sendo Guiomar Lopes filha de João Rodrigues Ferro, é provável que Filipa Lopes fosse irmã da mulher deste. Francisco Rodrigues era irmão de Filipa Lopes, assim como Filipa Rodrigues, mulher de Bernardo Ferro, era irmã de ambos. Desconhecemos o nome cristão da mulher de João Rodrigues Ferro que apenas foi identificada pelo marido pelo nome judaico de Paloma. No entanto, Maria Draga indicava-a como irmã de sua mãe e chamara-lhe Isabel Lopes, quando questionada pelo inquisidor sobre o seu parentesco com João Rodrigues Ferro.

$97 \mathrm{TT}$, Inquisição de Évora, no 9238.

98 TT, Inquisição de Évora, no 8918. 
distribuía depois pelos cristãos novos da vila, por grande parte das pessoas que testemunharam nas inquirições feitas em Trancoso, por ordem da Inquisição. Preso e conduzido ao Tribunal de Évora seria com os dois familiares, também presos, o grande delator da comunidade cristã nova que bem conheciam ${ }^{99}$.

Como dissemos acima, os grandes denunciantes da gente de Nação, residente em Trancoso, quando da primeira vaga de prisões em Évora, foram três sapateiros ${ }^{100}$, bem conhecedores das pessoas da comunidade, pois eram degoladores e auxiliavam no amortalhamento dos cristãos novos falecidos, ao mesmo tempo que eram os seus coveiros. Pelos seus depoimentos, temos o retrato da comunidade, dos que tinham ficado e dos que, com medo da Inquisição, conseguiram fugir para Espanha, Itália ou tinham partido por razões de negócio para mais longe, como o Peru, ou se tinham ausentado para parte desconhecida. Segundo eles, não haveria em Trancoso três cristãos novos que fossem bons cristãos.

Apesar do elevado número de detenções por culpas de judaísmo, os cristãos novos de Trancoso puderam beneficiar do perdão geral de 1547, pelo que, alguns após longa prisão e acusação de judaizarem no próprio cárcere inquisitorial, viriam a sair em liberdade com permissão para voltar a Trancoso. Nem todos o fariam e quando o fizeram o seu estatuto social deteriorara-se pela infâmia da prisão e pelo empobrecimento, ocasionado pelo longo pleito judicial.

A mobilidade, que já era uma realidade, tornou-se uma resposta ao desejo de anonimato e de rompimento com um passado recente ignominioso. As famílias cristãs novas começavam a dispersar-se por aldeias onde não existia a memória da presença judaica. Beatriz Fernandes, natural e moradora em Trancoso, na Rua Chã, estava casada com o carniceiro Francisco Rodrigues. Presa, viria a confessar ter praticado a religião judaica em casa de sua tia moradora em Ranhados. Os seus irmãos residiam, uns em Trancoso, outro em Pinhel, outro casara em Vila Real e fora viver para este concelho e outros casaram em S. João da Pesqueira e lá residiam. Um deles, o mercador Simão Fernandes, casado com Beatriz Pinheira, fugira para Bilbau e a mãe deles, viúva, saíra do reino desconhecendo o seu paradeiro ${ }^{101}$.

Já Francisca Lopes era natural do Grajal, nos arredores de Trancoso. Os pais, Jorge Vaz, já falecido, e Clara Gonçalves aqui tinham residido. Nesta aldeia moravam a tia, Catarina Fernandes casada com Manuel Dias, tratante, e os irmãos, Fernão Jorge, casado com Joana Mendes, Isabel Lopes, mulher de Domingos Lopes, Guiomar Lopes, casada com Diogo Vaz, alfaiate, Maria Lopes, casada

\footnotetext{
99 TT, Inquisição de Évora, $\mathrm{n}^{\circ} 7512$. Vide Anexo.

100 André Gonçalves, António Gonçalves e Duarte Gonçalves, já mencionados.

101 TT, Inquisição de Évora, $\mathrm{n}^{\circ} 6136$.
} 
com Fernão Lopes, e Filipa Lopes, mulher de Manuel Garcia. Uma tia, Graça Fernandes, viúva, residia em Gradis, aldeia vizinha. Francisca Lopes fora casar a Trancoso com Duarte Ferreira que fora sapateiro e se tornara tratante. Do seu casamento nascera um menino que tinha seis anos, na altura da prisão da mãe.

Das confissões conclui-se que a doutrinadora da família era Clara Gonçalves que, na casa no Grajal, ensinara às filhas e aos netos o cumprimento da Lei de Moisés. O mesmo viria a fazer Francisca Lopes com o marido. Acreditavam na vinda do Messias, guardavam o sábado, jejuavam os jejuns dos judeus, incluindo o quipur, que ocorria no tempo das vindimas.

A família viria a ser denunciada e presa na Inquisição de Coimbra, em 1569. Francisca Lopes sairia no auto da fé, realizado na Praça de Coimbra, a 24 de Julho do mesmo ano, sendo condenada a cárcere e hábito ao arbítrio, embora na sentença, tivesse sido lido que o hábito era perpétuo. A 28 do mesmo mês era-lhe dado Coimbra e os arredores como cárcere, devendo ir aos domingos e dias santos às missas e ouvir as pregações e doutrina e sendo obrigada a trazer sempre o hábito penitencial por cima da roupa. A 27 de Agosto, foi considerada doutrinada e por causa da peste que grassava na cidade foi-lhe dada autorização para regressar a Trancoso e foi-lhe levantada a penitência de cárcere e hábito perpétuo. Deveria confessar-se nas três Páscoas do ano e tomar os sacramentos, aconselhando-se com o confessor, assim como era obrigada a jejuar todas as sextas-feiras até ao Natal, rezando em cada uma delas o rosário em honra de Nossa Senhora ${ }^{102}$.

Exemplo semelhante era o da família de Beatriz Mendes, casada com o mercador Francisco Dias, e filha de Heitor Mendes, mercador, e de Ana Lopes, já falecidos ambos. Também ela confessava ter sido ensinada na religião judaica pela sua prima Violante Henriques ${ }^{103}$, ausente em Roma, e por Isabel de Almeida. A sua família permanecia, em parte, em Trancoso. Os irmãos tinham partido para aldeias, onde viviam com as respectivas famílias. Assim, Gonçalo Mendes, mercador, fora residir para Goujoim, perto de Lamego, Fernão Mendes, também mercador, casado com Maria Henriques, habitava em Rio de Moinhos, e Jerónimo Mendes, físico, casado com Leonor Gomes, fora para Viseu. O mesmo acontecia com os filhos: uns estavam casados ou solteiros a morar em Trancoso, uma filha fora casar em Castelo Mendo, outra em Aveiro e um filho fora viver com a mulher para Lisboa ${ }^{104}$.

102 TT, Inquisição de Coimbra, no 7749.

103 No processo de Violante Henriques, presa, mulher de Pedro Gonçalves mercador e tabelião em Trancoso, faz-se referência a outra Violante Henriques, mulher de Francisco Sanches, que trabalhava na corte, os quais fugiram para Itália (TT, Inquisição de Évora, $\mathrm{n}^{\circ}$ 8865).

104 TT, Inquisição de Coimbra, no 9662. 
Porém o estigma de suspeição de heresia continuaria a acompanhá-los e aos seus descendentes. Alguns seriam reincidentes nas culpas, como Branca Rodrigues, mulher do sapateiro João Dias, que fora presa na década de 40, em Évora. Agora, integrava um rol de cristãos novos de Trancoso, de Pinhanços, da Meda, de Alfaiates, de Pinhel, de Vila Real e de Lamego que os inquisidores de Coimbra mandavam as justiças prender. Branca Rodrigues, moradora na Rua da Cadeia, em Trancoso, fora acompanhada nesta sua viagem até Coimbra, por Beatriz Nunes que viera de S. João da Pesqueira, residir em Trancoso, por Ana Fernandes, viúva de Fernão Lopes, «»> baboso», azeiteira, e moradora à porta de S. João.

Branca Rodrigues era filha de mestre Tomás, físico, e de Clara Dias, ambos já falecidos e em vida residentes em Trancoso. Apenas tinha uma irmã, casada com um cristão velho, e residente em Muxagata. Ela casara com um cristão novo, João Dias, sapateiro, de quem teve dois filhos, Jorge Dias, tratante, casado com uma cristã nova, e Clara Rodrigues, casada com António Rodrigues, também tratante.

Chegada ao tribunal, Branca Rodrigues pediu audiência para confessar as suas culpas, incluindo a da prisão anterior de onde fora livre por não ter sido achada com culpas de judaísmo, teria então entre 20 a 30 anos de idade. Acusava de ter seguido a religião judaica instigada por Isabel Lopes, a «terrapala» ${ }^{105}$, já falecida e que estivera presa também na década de 40, na cidade de Évora e Filipa Fernandes, viúva de Diogo Fernandes, residente na Rua da Cadeia, como ela. Fazia os jejuns, guardava os sábados e a Páscoa. Nesta comiam os pães ázimos e quando os não podiam cozer, comiam durante os oito dias grão e castanhas, sempre em louça nova. Esperava o Messias dos judeus e rezava a Deus dos céus. Em vez das orações cristãs, rezava de manhã e à noite as orações dos judeus, como:

[...] seja formosura de Nosso Senhor, nosso Deus sobre nós, feito de nossas mãos; seja encoberto do alto a sombra do abastado me adormeço, digo Adonai, meu abrigo, meu castelo, meu Deus, nele (...?) eu.

A outra oração era

Cantar aos degraus a David de Adonai: Alço meus olhos aos montes donde vem a minha ajuda, minha ajuda do Senhor que fez os céus e a terra rica e por serem [...].

Juntavam-se-lhes nas práticas judaicas a filha de Isabel Lopes, «a terrapala», Ana Fernandes, mulher de Diogo Francisco, ambos presos em Coimbra, e a filha de Filipa Fernandes, Leonor. Mais tarde, acusaria também o marido a quem incitara

105 TT, Inquisição de Évora, $\mathrm{n}^{\mathrm{o}} 7175$. 
a jejuar à maneira judaica, quando estivera doente e com quem nunca mais falara sobre estes assuntos, «por ser homem que sabe pouco» e ensinaria a crença judaica aos filhos, nora e genro, assim como a Isabel Lopes, mulher de Simão Lopes, moradora na Corredoura, dizendo-lhes que era a verdadeira fé para a salvação da alma. No interrogatório, ainda lhe foi perguntado se tinha pedido a alguém para jejuar pela saúde do marido da sobrinha que vivia em Celorico ou se alguma vez deitara gotas de azeite numa tigela de água e invocara Adonai. Seria recebida com cárcere e hábito perpétuo para ser bem doutrinada, tendo saído no auto da fé de 20 de Agosto de 1570, em Coimbra. Já em penitência, lembrar-se-ia de confessar que praticara a Lei de Moisés com Filipa Nunes, cristã nova de Trancoso, mulher de Luís do Vale, filha de Leonor de Sousa, e com Ginebra Dias, «a caravelote», mulher de Manuel Dias, sapateiro, ambas presas em Coimbra. No ano seguinte, ser-lhe-ia levantado o cárcere e, atendendo a que estava suficientemente instruída na fé cristã, era-lhe permitido ir viver para Trancoso ${ }^{106}$.

Miguel Luís, homem solteiro, era filho de Lucrécia Rodrigues, presa em Coimbra, e do médico João Luís Medina que fora preso em Évora e solto com o perdão geral de $1547^{107}$, e que, entretanto, falecera em Ferreirim. Nessa altura, também estivera preso o tio Gabriel Dias, de Lamego que fora dado sem culpa provada. Um dos irmãos fora viver em Lisboa com a mulher Clara Gomes. Vendia ferragens aos ferradores. Os restantes irmãos residiam em Trancoso, onde tinham constituído família, com excepção de Isabel Luís, mulher de Manuel Francisco, residente em S. João da Pesqueira. Eram eles: Diogo Rodrigues, médico, casado com Antónia Nunes; Luísa Rodrigues, mulher de Jerónimo Henriques; Helena Luís, casada com Rodrigo Antunes, que vivia da sua fazenda, assim como Ana Luís, mulher de Diogo Febus.

Miguel Luís seria acusado de subornar com prendas e dinheiro o carcereiro para saber notícias de sua mãe e de outros presos de Trancoso, pelo que fora condenado a ser degredado para o Brasil, durante três anos, e a pagar 300 cruzados para as despesas do Sto. Ofício. O degredo viria a ser-lhe comutado e a pena substituída por degredo em Castro Marim, durante quatro anos por se encontrar doente ${ }^{108}$.

Manuel Fernandes e a sua mulher Inês, filho e nora de António Gonçalves, sapateiro de Trancoso, passaram a residir em Évora na Rua da Mouraria ${ }^{109}$. Este

106 TT, Inquisição de Coimbra, $\mathrm{n}^{\mathbf{o}} 238$.

107 TT, Inquisição de Évora, $\mathrm{n}^{\circ} 5305$.

108 TT, Inquisição de Coimbra, ${ }^{\circ} 64$.

109 Este espaço seria, em Évora, ocupado por cristãos novos não originários desta cidade. Na sua maioria eram descendentes dos judeus castelhanos que tinham ficado no reino e aqui tinham recebido as águas do baptismo. 
último fora com seu pai André Gonçalves e o primo de ambos, Duarte Gonçalves, acima referidos, um dos grandes denunciantes da comunidade cristã nova de Trancoso, em 1540. Os três estiveram presos em Évora e pelo Alentejo teria ficado a residir António, enquanto o pai regressava a Trancoso. Vinte anos mais tarde cairiam sob a alçada da Inquisição Manuel Fernandes e a sua mulher que confessariam ter aderido temporariamente à Lei de Moisés, o primeiro alegando que crera na religião dos seus antepassados depois de ter lido o livro «Espelho da Consolação dos tristes» ${ }^{110}$, acabando por confessar que o pai lhe ensinara a guardar o sábado e uma oração hebraica que costumava dizer: «Bento tu Adonai, nosso Deus, donde sempre que nos mandou nos encomendou suas [... $] \gg{ }^{111}$.

Também Domingos Pinheiro, almocreve e recoveiro dos estudantes de Coimbra, seria mandado prender pelos inquisidores de Coimbra, com ordem para inventário e sequestro de bens, acusado de utilizar as deslocações a esta cidade para saber informações dos presos de Trancoso, nomeadamente da madrasta Maria de Fonseca que estava presa por culpas de judaísmo, e tentativa de compra dos guardas da Inquisição com a oferta de queijos, marmelada, farinha, carne, etc. Seria condenado a degredo dos bispados de Coimbra e de Viseu, durante um ano, com indicação de não ser livre enquanto não fossem feitas todas as diligências sobre o seu comportamento religioso.

Domingos Pinheiro era filho do casamento de Manuel Pinheiro com uma cristã velha de nome Isabel, ambos já falecidos. Os tios paternos residiam em Trancoso como Simão, Jorge e Isabel, enquanto Sebastião Pinheiro se mudara para Lisboa e duas das tias foram casar a Celorico, uma, à Guarda, a outra e aí residiam. O segundo casamento do pai fora já com uma cristã nova Maria de Fonseca, que se encontrava presa. Ele próprio se casara com uma cristã velha, Branca Luís, de quem tinha quatro filhos menores ${ }^{112}$.

Isabel Nunes nascera na Guarda, na Rua Nova, e fora casar pela segunda vez a Trancoso com Jorge Gonçalves, alfaiate. O primeiro marido residira na Covilhã e aqui morrera. Os pais eram Simão Fernandes, «o parido», e Leonor Gomes, esta última presa em Coimbra por culpas de judaísmo. Os tios paternos residiam em Viseu, na Guarda e no Teixoso.

A crença judaica partilhou-a na Guarda com a mãe e outras cristãs novas, sendo a «rabina» do grupo uma Violante Nunes, já falecida, que recitava as orações dos judeus que as demais repetiam em voz alta. Viria a ser condenada a cárcere e hábito perpétuo sem remissão e com fogos e sairia no auto da fé de

\footnotetext{
110 Talvez a obra de Samuel Usque, Consolação às tribulações de Israel.

111 TT, Inquisição de Évora, $\mathrm{n}^{\text {os }} 9764$ e 8008 (ano 1561).

112 TT, Inquisição de Coimbra, no 3761.
} 
1 de Agosto de 1568. A pena seria substituída por penas espirituais em Trancoso e em Abril de 1570 ser-lhe-ia permitido abandonar o hábito ${ }^{113}$.

Bernardo Lopes, residente em Trancoso, na Rua Chã, freguesia de S. João, foi acusado de judaizar pelos irmãos e pela mulher, presos em Lisboa e em Coimbra. A família encontrava-se dispersa por Trancoso, Marialva, Celorico e Lisboa. Bernardo Lopes fora casar a Celorico de onde a mulher, Briolanja Rodrigues, era natural. Fora baptizado e crismado na igreja de S. João, em Trancoso, e sabia os rudimentos da doutrina cristã com excepção dos artigos da fé. Acabaria por confessar que aprendera as orações judaicas com o pai e recitou algumas:

Alto Deus de Abraão, Rei forte de Israel, Tu que ouviste Ismael, ouve a minha oração, Tu que nas altas alturas te aposentaste [...] ouveme a mim pecador que estou nestas baixuras; Tu que a toda a criatura, abres caminhos e pontes. [...] Alcei meus olhos aos montes donde virá minha ajuda; [...] Deitemo-nos agora e cada hora em poder de Adonai que [...] muitas são as piedades para nos haver de apiedar.

Acrescentava que se tinha declarado judeu com os irmãos, a mulher e outros familiares. Uns estavam presos pelas mesmas culpas, outros tinham ido residir em Madrid, como Jorge Fernandes e Gaspar Lopes, ambos tratantes. De Espanha, tinha recebido um livro em favor da religião judaica que um Pedro Rodrigues, provavelmente irmão de Briolanja, mandara a seu irmão António Rodrigues, também preso em Coimbra. No entanto, a sua confissão seria entendida incompleta, porque não acusara os cunhados, pelo que seria posto a tormento. Sairia com hábito penitencial com insígnias de fogo à frente e nas costas, e condenado a cárcere e hábito penitencial perpétuo, sem remissão, no auto da fé na Praça de Coimbra, a 27 de Junho de 1593. A cidade de Coimbra foi-lhe dada por cárcere, devendo aprender a doutrina cristã no Colégio da Companhia de Jesus neste cidade. Um ano mais tarde, em Setembro de 1594, o cura da igreja de Santiago de Trancoso certificaria o Tribunal de que ele estava catequizado e se confessava e comungava pelo Natal e pela Páscoa. Em 1603, era-lhe retirado o hábito ${ }^{114}$.

Na Inquisição de Coimbra, também caiu um neto do tabelião João da Fonseca e de Violante Nunes, e de João Fernandes «Pé de ginja», que acabaria entregue à justiça secular. Álvaro da Fonseca Ferraz, de alcunha

\footnotetext{
113 TT, Inquisição de Coimbra, $\mathrm{n}^{\circ} 8198$.

114 TT, Inquisição de Coimbra, n 331.
} 
o «Narigão» (o velho), casado com Beatriz de Mercado, era filho de António Ferraz e de Ana Fonseca, já falecidos na altura da prisão do filho. Era acusado de práticas judaicas por vários parentes como Manuel da Fonseca Rego, residente em Trancoso, por Lopo da Fonseca, mercador e morador em Viseu, por Brás Lopes «Nyam», entre outros.

Álvaro da Fonseca Ferraz era abastado proprietário, tal como o seu irmão João da Fonseca Henriques, sendo ambos proprietários da quinta de Vale Dianteiro, junto da Torre de Terrenho, nos arredores de Trancoso. No caminho para a quinta, na Praça de Trancoso, no adro da Misericórdia, os primos e outros cristãos novos, seus parentes, residentes na vila confessavam-se uns aos outros judeus, guardando os jejuns, a abstinência da carne de porco e o descanso sabático. O sangue gerava confiança entre parentes, confiança que se tornava perigosa quando um dos membros caía sob a alçada da Inquisição, tanto mais que a família não abonava muito a favor da sua fidelidade ao cristianismo, desde os avós paternos e maternos que tinham tido culpas e sido denunciados na primeira entrada da Inquisição em Trancoso, em 1540. Um dos tios paternos, Miguel de Sousa, residente em Bragança, tinha sido entregue à justiça secular pela Inquisição de Lisboa. Também duas tias maternas, já falecidas, Florença da Fonseca, casada em Seia com o licenciado Henrique Fernandes, e Beatriz da Fonseca, casada em Marialva com Gaspar Soares, tinham estado presas e saído com hábito. O mesmo sucedera com a mulher, Beatriz de Mercado. Tinha dois filhos solteiros: Ana da Fonseca e Pedro Lopes de Morais.

Negou sempre as culpas de judaísmo, afirmando-se bom cristão, excepto quando foi posto a tormento. Fora baptizado na igreja de S. Pedro de Trancoso e crismado na igreja de Moreira pelo bispo de Viseu. Conhecia as orações básicas do cristianismo e as testemunhas de defesa, párocos de $\mathrm{S}$. Pedro e de S. Tiago, assim como a gente grada cristã velha do concelho, tinham-no por bom cristão e cumpridor dos preceitos da Igreja.

Na prisão, Álvaro da Fonseca Ferraz, em conversa com outros prisioneiros, elogiava a França, lamentando não ter abandonado o país e esperava ardentemente que o rei Filipe III casasse com uma francesa, para ver se as perseguições aos cristãos novos acabavam. Acabaria por fazer-se passar por doido o que não convenceu os inquisidores que, depois de o terem condenado a tormento, o condenariam a ser entregue à justiça secular, porque a confissão de crente na Lei de Moisés, fé que professava graças aos ensinamentos de sua mãe já falecida, fora tida por insuficiente. Acompanhá-lo-ia nos últimos momentos o jesuíta Simão Álvares ${ }^{115}$.

Em Lisboa, para onde fora residir após as prisões da década de 40, que atingiram alguns familiares seus, foi preso Carlos Francisco, filho de Francisco

115 TT, Inquisição de Coimbra, $\mathrm{n}^{\circ} 621$. 
Carlos — um dos rabis da comunidade de Trancoso naquela altura —, e de Maria Draga, e neto de Mestre Carlos e de Fernão Drago, respectivamente avôs paterno e materno. Os tios paternos e maternos eram, na altura da sua prisão, todos já falecidos: Manuel Carlos, Ana do Vale, Isabel do Vale e Clara Carlos, da parte paterna, e Manuel Drago e Bernardo Drago, do lado da mãe.

Foi acusado de práticas judaicas que negou e trouxe à colação o seu bom cristianismo, alegando ter instituído a confraria do Espírito Santo na ilha de S. Tomé de que foi várias vezes mordomo, dado ter vivido na ilha durante seis anos, na década de 50, assim como tinha pertencido à Mesa da Misericórdia, em Lisboa. Para além das testemunhas abonatórias, todas cristãs velhas, juntou a constituição da companhia de Francisco Rodrigues Milão, Henrique Rodrigues, seu irmão, e Jorge Francisco, de que foi feitor em S. Tomé, de 1549 a 1556 e depois de 1557 a 1562 . Foi absolvido das acusações.

Seu irmão Jorge Carlos radicara-se em S. Tomé e aqui falecera, assim como um seu cunhado Diogo Soares. Aqui tinham constituído uma sociedade familiar com membros em Lisboa, em S. Tomé e no Brasil que se dedicava ao tráfico de escravos de África para o Brasil e ao comércio do açúcar para a Europa ${ }^{116}$.

Não seriam os únicos membros desta família a ter relações económicas com África, nem tão pouco com outras regiões da Europa. A Inquisição tinha-os dispersado pelo reino e o seu império, mas também pelo continente europeu, mantendo sempre a união do património familiar, sobretudo do que assentava nas parcerias em sociedades comerciais familiares. Os Drago encontravam-se-lhes associados, mesmo quando emigrados em Itália, nomeadamente, em Veneza. A chegada a Lisboa de João Baptista Drago proveniente de Veneza onde vivia como judeu assumido, para tomar parte nos bens da família criou alguns problemas aos parentes que residiam em Portugal.

Assim, logo que aportou na capital, João Baptista dirigiu-se ao Tribunal da Inquisição para se reconciliar e pedir perdão da sua apostasia. No entanto, a sua presença tornava-se incómoda para os tios que decidiram enviá-lo para Angola e daqui para o Brasil com um carregamento de escravos, no valor de 800 cruzados de ouro. O feitor e representante dos tios, em S. Tomé, era João de Oliveira que, com o seu irmão Luís Gomes, seria denunciado por João Baptista como judaízante. Em Angola, o representante da sociedade era Gonçalo da Ribeira, parente da mulher de Bartolomeu Drago. De Angola, foi para o Recife com o seu primo Francisco Carlos, filho de Manuel Drago.

Regressado a Lisboa, os tios ofereceram-lhe 300 cruzados de ouro para re-

116 TT, Inquisição de Lisboa, no 12132. 
gressar a Itália o que recusaria, pois queria a parte que lhe cabia da herança do tio Jorge Carlos. Não tendo chegado a acordo com os familiares, decidiria enviar uma carta ao bispo de S. Tomé denunciando a comunidade cristã nova da ilha, assim como alguns membros da sua própria família, e o modo como estes ajudavam os cristãos novos a fugir do reino ${ }^{117}$.

Mais tarde, no início do século XVII, alguns descendentes dos Drago emigrariam para Amesterdão, prolongando com os laços familiares, as redes comerciais das sociedades familiares constituídas, ramificando-as agora para o norte da Europa ${ }^{118}$.

(Continuará)

117 TT, Inquisição de Lisboa. Caderno do Promotor, liv. 194, fls. 114-120.

118 David Franco Mendes, Memorias do estabelecimento e progresso dos judeos portuguezes e espanhoes nesta famosa cidade de Amsterdam (Assen 1975), pp. 78 e 116. 